\title{
Decadal trends in global CO emissions as seen by MOPITT
}

\author{
Y. Yin ${ }^{1}$, F. Chevallier ${ }^{1}$, P. Ciais ${ }^{1}$, G. Broquet ${ }^{1}$, A. Fortems-Cheiney ${ }^{2}$, I. Pison ${ }^{1}$, and M. Saunois ${ }^{1}$ \\ ${ }^{1}$ Laboratoire des Sciences du Climat et de l'Environnement, CEA-CNRS-UVSQ, UMR8212, Gif-sur-Yvette, France \\ ${ }^{2}$ Laboratoire Interuniversitaire des Systèmes Atmosphériques, CNRS/INSU, UMR7583, Université Paris-Est Créteil et \\ Université Paris Diderot, Institut Pierre Simon Laplace, Créteil, France
}

Correspondence to: Y. Yin (yi.yin@1sce.ipsl.fr)

Received: 20 April 2015 - Published in Atmos. Chem. Phys. Discuss.: 22 May 2015

Revised: 28 October 2015 - Accepted: 17 November 2015 - Published: 7 December 2015

\begin{abstract}
Negative trends of carbon monoxide (CO) concentrations are observed in the recent decade by both surface measurements and satellite retrievals over many regions of the globe, but they are not well explained by current emission inventories. Here, we analyse the observed CO concentration decline with an atmospheric inversion that simultaneously optimizes the two main CO sources (surface emissions and atmospheric hydrocarbon oxidations) and the main $\mathrm{CO}$ sink (atmospheric hydroxyl radical OH oxidation). Satellite $\mathrm{CO}$ column retrievals from Measurements of Pollution in the Troposphere (MOPITT), version 6, and surface observations of methane and methyl chloroform mole fractions are assimilated jointly for the period covering 2002-2011. Compared to the model simulation prescribed with prior emission inventories, trends in the optimized $\mathrm{CO}$ concentrations show better agreement with that of independent surface in situ measurements. At the global scale, the atmospheric inversion primarily interprets the $\mathrm{CO}$ concentration decline as a decrease in the $\mathrm{CO}$ emissions $\left(-2.3 \% \mathrm{yr}^{-1}\right)$, more than twice the negative trend estimated by the prior emission inventories $\left(-1.0 \% \mathrm{yr}^{-1}\right)$. The spatial distribution of the inferred decrease in $\mathrm{CO}$ emissions indicates contributions from western Europe $\left(-4.0 \% \mathrm{yr}^{-1}\right)$, the United States $\left(-4.6 \% \mathrm{yr}^{-1}\right)$ and East Asia $\left(-1.2 \% \mathrm{yr}^{-1}\right)$, where anthropogenic fuel combustion generally dominates the overall $\mathrm{CO}$ emissions, and also from Australia $\left(-5.3 \% \mathrm{yr}^{-1}\right)$, the Indo-China Peninsula $\left(-5.6 \% \mathrm{yr}^{-1}\right)$, Indonesia $\left(-6.7 \% \mathrm{yr}^{-1}\right)$, and South America $\left(-3 \% \mathrm{yr}^{-1}\right)$, where $\mathrm{CO}$ emissions are mostly due to biomass burning. In contradiction with the bottom-up inventories that report an increase of $2 \% \mathrm{yr}^{-1}$ over China during the study period, a significant emission decrease of $1.1 \% \mathrm{yr}^{-1}$ is inferred by the inversion. A large decrease in $\mathrm{CO}$ emission factors due to technology improvements would outweigh the
\end{abstract}

increase in carbon fuel combustions and may explain this decrease. Independent satellite formaldehyde $\left(\mathrm{CH}_{2} \mathrm{O}\right)$ column retrievals confirm the absence of large-scale trends in the atmospheric source of $\mathrm{CO}$. However, it should be noted that the $\mathrm{CH}_{2} \mathrm{O}$ retrievals are not assimilated and $\mathrm{OH}$ concentrations are optimized at a very large scale in this study.

\section{Introduction}

Carbon monoxide (CO) is an air pollutant that leads to the formation of tropospheric ozone $\left(\mathrm{O}_{3}\right)$ and carbon dioxide $\left(\mathrm{CO}_{2}\right)$. It is the major sink of the tropospheric oxidant hydroxyl radical $(\mathrm{OH})$, and hence influences concentrations of methane $\left(\mathrm{CH}_{4}\right)$ and non-methane volatile organic compounds (NMVOCs) (Logan et al., 1981). It contributes to an indirect positive radiative forcing of $0.23 \pm 0.07 \mathrm{~W} \mathrm{~m}^{-2}$ at the global scale (IPCC, 2013). Atmospheric CO has two main sources: (i) direct surface $\mathrm{CO}$ emissions from fuel combustion and biomass burning, estimated to be $\sim 500$ $600 \mathrm{TgCO} \mathrm{yr}^{-1}$ and $\sim 300-600 \mathrm{TgCO} \mathrm{yr}^{-1}$, respectively, by emission inventories (Granier et al., 2011, and references herein), and (ii) secondary chemical oxidation of hydrocarbons in the troposphere, estimated to be a source of $\sim 1200$ $1650 \mathrm{TgCO} \mathrm{yr}^{-1}$ with considerable differences among studies (Holloway et al., 2000; Pétron et al., 2004; Shindell et al., 2006; Duncan and Logan, 2008). The sink of CO is mainly through oxidation by OH (Logan et al., 1981), which defines an average lifetime of 2 months for $\mathrm{CO}$ in the atmosphere.

Surface in situ measurements in Europe (Zellweger et al., 2009; Angelbratt et al., 2011), over the USA (Novelli et al., 2003; EPA, 2015), in some large cities in China ( $\mathrm{Li}$ and Liu, 2011), and in many other places (Yoon and Pozzer, 
2014), indicate that CO concentrations have been decreasing for more than 10 years. Negative trends have also been observed by various satellite sensors (MOPITT; the Tropospheric Emission Spectrometer - TES; and the Atmospheric Infrared Sounder - AIRS) over most of the world (Warner et al., 2013; Worden et al., 2013). In particular, strong CO concentration decreases are seen from these satellite retrievals over eastern China and India (Worden et al., 2013), where bottom-up inventories report increasing emissions (Granier et al., 2011; Kurokawa et al., 2013).

Atmospheric chemistry transport models (ACTMs) prescribed with emission inventories are commonly used to analyse the role of emissions in the atmospheric concentration. Most of these simulations tend to underestimate $\mathrm{CO}$ concentrations in the middle to high latitudes of the Northern Hemisphere (NH), whereas they overestimate them over emission hotspots (Shindell et al., 2006; Duncan et al., 2007; Naik et al., 2013; Stein et al., 2014; Yoon and Pozzer, 2014). This bias reveals an incorrect balance between CO sources, at the surface and in the atmosphere, and CO sinks (Naik et al., 2013). Understanding this model-data misfit is challenging because surface emissions and chemical production each account for about half of the total CO sources, and because the sink term removes an amount of $\mathrm{CO}$ equivalent to all the sources within a few weeks. Changes in each source and sink term could have contributed to the observed $\mathrm{CO}$ concentration decrease, even though only $\mathrm{CO}$ emission trends are usually discussed (Khalil and Rasmussen, 1988; Novelli et al., 2003; Duncan and Logan, 2008).

In principle, the attribution of the mean balance between sources and sinks and of their trends can be made with Bayesian inversion systems that infer the $\mathrm{CO}$ budget terms based on (i) measurements of $\mathrm{CO}$ and species related to the $\mathrm{CO}$ sources and sinks, (ii) some prior information about the budget terms and spatial distributions, (iii) a CTM model to link emissions and chemistry to concentrations, and (iv) a description of the uncertainty in each piece of information. Various inversion studies have estimated regional or global $\mathrm{CO}$ budgets using $\mathrm{CO}$ surface observations (Bergamaschi et al., 2000; Pétron, 2002; Butler et al., 2005) or satellite retrievals (Arellano et al., 2004; Pétron et al., 2004; Stavrakou and Müller, 2006; Chevallier et al., 2009; Fortems-Cheiney et al., 2009, 2011, 2012; Kopacz et al., 2010; Hooghiemstra et al., 2012; Jiang et al., 2013). Here, we use the Python Variational - Simplified Atmospheric Chemistry (PYVARSACS) inversion system of Pison et al. (2009), Chevallier et al. (2009) and Fortems-Cheiney et al. $(2009,2011,2012)$ to infer the most likely origin of the observed $\mathrm{CO}$ concentration decrease over the past decade (2002-2011).

In contrast to most $\mathrm{CO}$ inversion systems cited above, which focused on a single species, PYVAR-SACS simultaneously assimilates observations of the main species in the chemical oxidation chain of $\mathrm{CH}_{4}-\mathrm{CH}_{2} \mathrm{O}-\mathrm{CO}$ and methyl chloroform (MCF), a species that only reacts with $\mathrm{OH}$ and therefore informs about its concentration. The PYVAR-
SACS system optimizes the interconnected sources and sinks of the four species in a statistically and physically consistent way at the model resolution of $3.75^{\circ} \times 2.5^{\circ}$ (longitude, latitude) on an 8-day basis, therefore being suitable for addressing the above-described attribution problem of the $\mathrm{CO}$ variations within the limit of the observation information content.

The primary data source about $\mathrm{CO}$ in this study is MOPITT, a multi-channel thermal infrared (TIR) and nearinfrared (NIR) instrument on board the EOS-Terra satellite (Deeter, 2003). MOPITT provides the longest consistent time series of satellite CO retrievals to date. The algorithm has undergone continuous improvements and the archive has been reprocessed several times (Deeter et al., 2013). Most of the above-cited satellite-based inversion studies used version 4 or earlier versions of the MOPITT CO retrievals, in which a noticeable instrumental drift was reported (Deeter et al., 2010). In version 5, this drift has been corrected together with other improvements (Deeter et al., 2013; Worden et al., 2013). Here, we use the further improved version 6 that has no noticeable bias in the trends of the CO total column (Deeter et al., 2014), to attribute the CO concentration decline by assimilation in our atmospheric inversion system.

The structure of the paper is as follows. Section 2 describes the inversion system and the data sets. Section 3 presents the inversion results on $\mathrm{CO}$ concentrations and associated trends. We show a brief evaluation of the inversion ability to fit the assimilated data and we cross-evaluate the optimized surface $\mathrm{CO}$ concentrations against independent station measurements. Then, we compare the $\mathrm{CO}$ concentration trend in the MOPITT retrievals, in the surface measurements, and in corresponding modelling results before and after the inversion. Section 4 shows the trend analysis of the prior and posterior simulated $\mathrm{CH}_{2} \mathrm{O}$ and $\mathrm{OH}$ concentrations. $\mathrm{CH}_{2} \mathrm{O}$ concentrations are representative of the chemical $\mathrm{CO}$ sources and we evaluate the model values against retrievals of its dry air column $\left(\mathrm{X}_{\mathrm{CH}_{2} \mathrm{O}}\right)$ made from observations of the Ozone Monitoring Instrument (OMI) aboard EOS Aura. $\mathrm{OH}$ regulates $\mathrm{CO}$ sinks, but is an extremely short-lived compound whose concentrations are difficult to measure (Mao et al., 2012). Lacking direct global observation data, we discuss its uncertainties with two contrasting prior $\mathrm{OH}$ fields. Section 5 presents the inverted $\mathrm{CO}$ budget, including atmospheric burden, emission, chemical production and chemical loss. Section 6 summarizes this work, discusses the sources of uncertainties and provides some perspectives for future works.

\section{Method and data}

\subsection{Inversion system}

The PYVAR Bayesian inversion system, initially introduced by Chevallier et al. (2005), aims at adjusting a series of target variables (jointly called $\boldsymbol{x}$ ), so that they become consistent with both the atmospheric observations $(\boldsymbol{y})$ and a priori state 


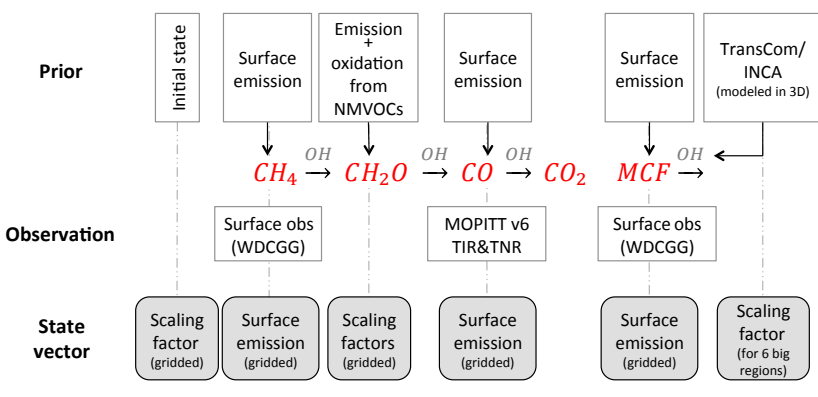

Figure 1. Schematics of the input information provided to the inversion and of the inversion state vector.

$\left(\boldsymbol{x}^{b}\right)$ given their respective uncertainties, represented by error covariance matrices $\mathbf{R}$ and $\mathbf{B}$. By iteratively minimizing the following cost function $J$, PYVAR finds the optimal solution for $x$ in a statistical sense:

$$
\begin{aligned}
J(\boldsymbol{x}) & =\frac{1}{2}\left(\boldsymbol{x}-\boldsymbol{x}^{b}\right)^{T} \mathbf{B}^{-1}\left(\boldsymbol{x}-\boldsymbol{x}^{b}\right) \\
& +\frac{1}{2}(\mathbf{H}(\boldsymbol{x})-\boldsymbol{y})^{T} \mathbf{R}^{-1}(\mathbf{H}(\boldsymbol{x})-\boldsymbol{y}),
\end{aligned}
$$

where $H$ is the combination of a CTM and of an interpolation operator that includes the combination with the retrieval prior $\mathrm{CO}$ profiles and averaging kernels (AKs) for MOPITT.

Our CTM is the general circulation model of Laboratoire de Météorologie Dynamique (LMDz) version 4 (Hourdin et al., 2006), nudged towards winds analysed by the European Centre for Medium-Range Weather Forecasts, run in an off-line mode with precomputed atmospheric mass fluxes, and coupled with the SACS chemistry module (Pison et al., 2009). SACS is a simplification of the Interaction with Chemistry and Aerosols (INCA, Hauglustaine, 2004) full chemistry model.

The chemical chain is shown in Fig. 1. It includes surface emissions of $\mathrm{CO}, \mathrm{CH}_{4}, \mathrm{CH}_{2} \mathrm{O}$ and MCF. The 3-D contribution of NMVOC oxidation to $\mathrm{CH}_{2} \mathrm{O}$ production has been precalculated by the LMDz-INCA (Folberth et al., 2006). OH links all the species together. Reaction kinetic and photolysis rates, as well as fields of species that are not represented as tracers in PYVAR-SACS (e.g. $\mathrm{O}_{1} \mathrm{D}, \mathrm{O}_{2}, \mathrm{Cl}$ ), are based on the LMDz-INCA simulation. The initial states are produced by LMDz-INCA. The CTM in PYVAR-SACS has a time step of $15 \mathrm{~min}$ for the dynamics (advection) and of $30 \mathrm{~min}$ for the physics (convection, boundary layer turbulence) and chemistry, a horizontal resolution of $3.75^{\circ} \times 2.5^{\circ}$ (longitude, latitude), and a vertical resolution of 19 eta-pressure levels from the surface to the top of the atmosphere.

The state vector $\boldsymbol{x}$ contains the following variables as shown in the grey boxes in Fig. 1: (1) grid-point scaling factors for the initial mixing ratios of the four trace gas species (CO, $\mathrm{CH}_{4}, \mathrm{CH}_{2} \mathrm{O}, \mathrm{MCF}$ ); (2) grid-point 8-day mean surface emissions of $\mathrm{CO}, \mathrm{CH}_{4}$, and MCF; (3) grid-point 8-day scaling factors to adjust the sum of $\mathrm{CH}_{2} \mathrm{O}$ surface emissions and $\mathrm{CH}_{2} \mathrm{O}$ production from NMVOC oxidation; and (4) 8-day scaling factors to adjust the column-mean $\mathrm{OH}$ concentrations over six big boxes of the atmosphere over the globe: three latitudinal boxes $\left(90-30^{\circ} \mathrm{S}, 30^{\circ} \mathrm{S}-0^{\circ}, 0^{\circ}-30^{\circ} \mathrm{N}\right)$ and three longitudinal boxes north of $30^{\circ} \mathrm{N}$ (North America: $180-45^{\circ} \mathrm{W}$; Europe: $45^{\circ} \mathrm{W}-60^{\circ} \mathrm{E}$; Asia: $60-180^{\circ} \mathrm{E}$ ). The longitudinal division of the band north of $30^{\circ} \mathrm{N}$ is an improvement compared to previous PYVAR studies, with four latitudinal bands in total to optimize $\mathrm{OH}$. As there are available surface stations with long-term MCF observations within each of the sub-regions, this allows adjusting of separately continental differences of $\mathrm{OH}$.

\subsection{A priori information}

Previous configurations of PYVAR-SACS have been described by Chevallier et al. (2009) and Fortems-Cheiney et al. (2011). We have improved the configuration as described below.

\subsubsection{Prior sources and sinks}

For prior anthropogenic fossil fuel and biofuel $\mathrm{CO}$ emissions, we use the monthly MACCity emission inventory of Lamarque et al. (2010) that arguably underestimates emissions less than other global inventories (Granier et al., 2011; Stein et al., 2014). For biomass burning, we updated the version of Global Fire Emissions (GFED) from version 2 (van der Werf et al., 2006) to version 3.1 (Van der Werf et al., 2010). The latter has various improvements including the definition of different fire types, with specific consideration for deforestation and peatland fires. We also increased the temporal resolution of biomass burning emissions from monthly to weekly (aggregated from GFEDv3.1 daily emissions, $\mathrm{Mu}$ et al., 2011). Additionally, we consider in this study biochemical $\mathrm{CO}$ emissions from oceans that were neglected before, based on an ocean biogeochemical model simulation (Aumont and Bopp, 2006). These monthly ocean CO fluxes add up to a global annual sum of $54 \mathrm{TgCO} \mathrm{yr}^{-1}$ without inter-annual variability. We still consider neither biogenic $\mathrm{CO}$ emissions over land nor surface $\mathrm{CO}$ deposition, because these two terms are relatively small and are of a similar order of magnitude (Duncan et al., 2007). The prior CO emissions are summarized in Table 1 and the distribution of the mean annual prior CO surface emissions is shown in Fig. 2a. The relative contribution of biomass burning is shown in Fig. $2 b$.

The prior $\mathrm{CH}_{4}$ and $\mathrm{MCF}$ emissions have also been updated compared to Fortems-Cheiney et al. (2012) and are similar to that of Cressot et al. (2014). HCHO production prior fields have been pre-calculated by LMDz-INCA (Folberth et al., 2006), with prescribed NMVOC emission data sets detailed in Fortems-Cheiney et al. (2012). The prior distribution of mean annual $\mathrm{CO}$ chemical sources in the troposphere from the oxidation of both $\mathrm{CH}_{4}$ and NMVOCs is shown vertically integrated in Fig. 2c. 
Table 1. Prior data sets for the sources and sinks of CO. Mean annual sums are calculated for the period from 2002 to 2011 . The global annual prior error budgets are reported and the TransCom-OH field is used. The sum of surface emissions and chemical sources are shown in bold.

\begin{tabular}{|c|c|c|c|c|}
\hline & Sectors & $\begin{array}{l}\text { Mean annual } \\
\text { sum }\left(\operatorname{Tg~yr}^{-1}\right)\end{array}$ & $\begin{array}{l}\text { Data set/ } \\
\text { model }\end{array}$ & References \\
\hline \multirow[t]{10}{*}{$\mathrm{CO}$} & Sources: & & & \\
\hline & Biomass burning & 327 & GFEDv3.1 & Van der Werf et al. (2010) \\
\hline & Anthropogenic emissions & 588 & MACCity & Lamarque et al. (2010) \\
\hline & Ocean & 54 & PISCES & Updated from Aumont et al. (2006) \\
\hline & Sum of surface emissions & $969 \pm 180^{\mathrm{a}}$ & & \\
\hline & Oxidation from NMVOC & $335 \pm 43^{\mathrm{b}}$ & LMDz-INCA & Folberth et al. (2006) \\
\hline & Oxidation from $\mathrm{CH}_{4}$ & $885 \pm 92^{c}$ & & \\
\hline & Sum of chemical sources & 1220 & & \\
\hline & Sinks: & & & \\
\hline & Oxidation by $\mathrm{OH}$ & 2197 & TransCom-OH & Patra et al. (2011) \\
\hline
\end{tabular}

\footnotetext{
a The uncertainty represents the SD of the global annual error budgets in the prior CO emissions in the inversion configuration. ${ }^{\mathrm{b}}$ The SD is calculated into the equivalent $\mathrm{CO}$ amount from global annual error budgets of the pre-calculated $\mathrm{CH}_{2} \mathrm{O}$ production fields. ${ }^{\mathrm{c}}$ The $\mathrm{SD}$ is calculated into the equivalent $\mathrm{CO}$ amount from global annual error budgets of the prior $\mathrm{CH}_{4}$ emissions assuming they are all oxidized into $\mathrm{CO}$ in a single step. The prior $\mathrm{CH}_{4}$ emission (506 $\mathrm{TgCO} \mathrm{yr}^{-1}$ ) data sets are detailed in Cressot et al. (2014).
}
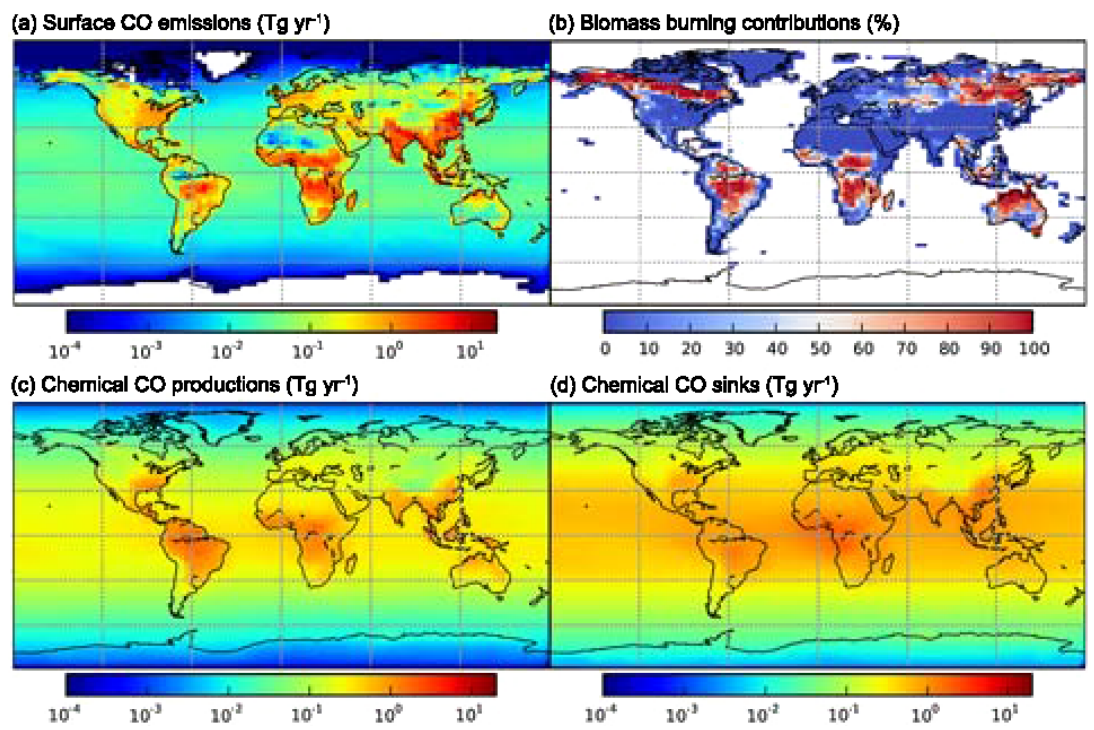

Figure 2. Distribution of prior budget terms for CO. Annual mean values per each model grid (2.5 latitude $\times 3.75$ longitude) from 2002 to 2011 are shown. (a) Surface CO emissions, (b) relative percentages of CO emissions from biomass burning over land, (c) atmospheric $\mathrm{CO}$ productions from $\mathrm{CH}_{4}$ and NMVOC, and (d) atmospheric $\mathrm{CO}$ chemical sinks. The chemical productions and sinks are calculated with TransCom-OH.

Previous PYVAR-SACS studies used prior OH information from a multi-year simulation by LMDz-INCA (Hauglustaine, 2004). Here, we use another field that was prepared for the international TransCom- $\mathrm{CH}_{4}$ experiment of Patra et al. (2011). The annual mean horizontal and vertical distribution of $\mathrm{OH}$ concentrations for both $\mathrm{OH}$ fields and their differences are shown in Fig. 3. Compared to the INCA-OH, the TransCom $\mathrm{OH}$ has a lower $\mathrm{OH}$ concentration in the $\mathrm{NH}$, and a lower concentration over the tropics and the Southern Hemisphere (SH). Thus, the TransCom-OH has a northsouth inter-hemisphere ratio of around 1 , whereas the INCA-
$\mathrm{OH}$ has a ratio of 1.2. There are also vertical differences between these two $\mathrm{OH}$ fields: in general, TransCom-OH has higher $\mathrm{OH}$ concentrations in the mid-troposphere over the tropics and in the top layers above $100 \mathrm{hPa}$, whereas INCA$\mathrm{OH}$ has higher $\mathrm{OH}$ concentrations in the lower troposphere below $700 \mathrm{hPa}$. The prior distribution of the CO sinks simulated with TransCom-OH is shown vertically integrated in Fig. 2d. 

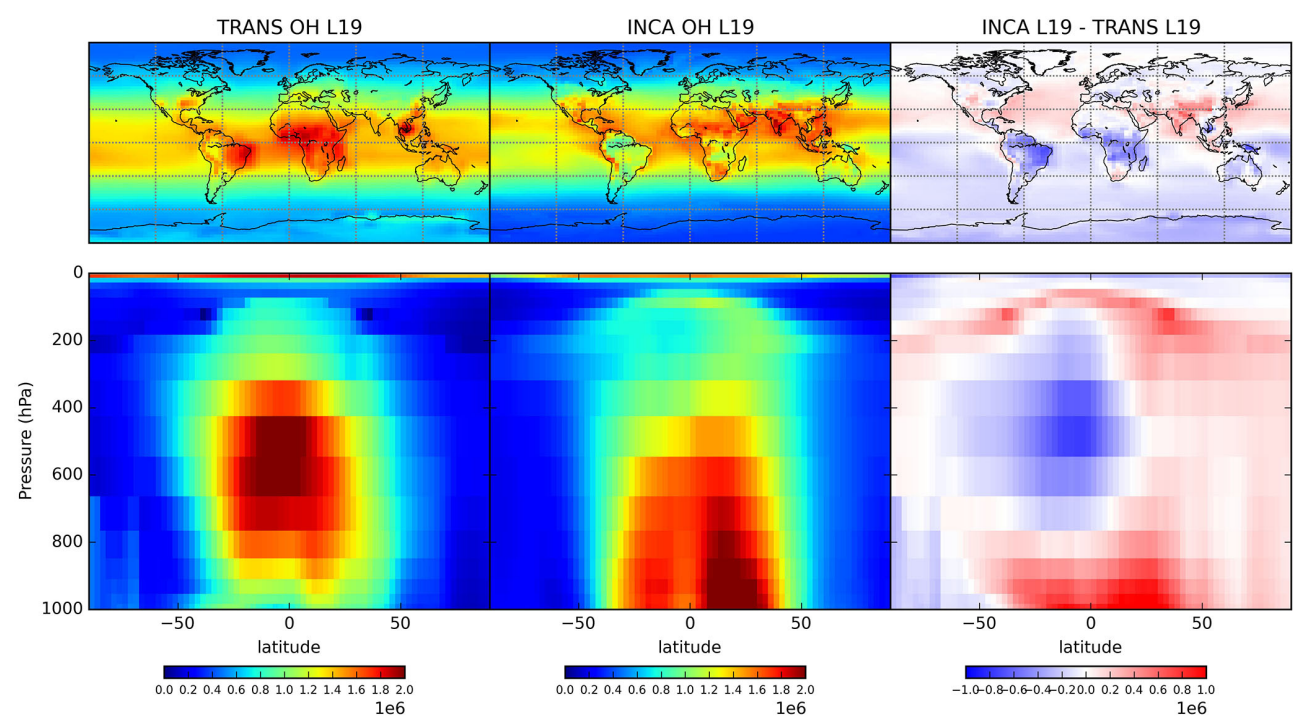

Figure 3. Spatial and vertical distribution of $\mathrm{OH}$ concentration in TransCom and INCA and their relative differences. The TransCom $\mathrm{OH}$ is interpolated from its original 60 pressure levels into the LMDz 19 eta-pressure levels.

\subsubsection{Prior error statistics}

The prior flux uncertainty, defined by the standard deviation (SD) of each grid-point 8-day flux, is described below. For CO emission uncertainties, we define the SD for each year based on the maximum value of the emission time series during the corresponding year for each grid point (noted as $f_{\max }$ ), in order to account for the uncertainty of the fire timing. Then, to account for (i) the possibility of undetected small fires that can contribute to as much as $35 \%$ of the global biomass burning carbon emissions (Randerson et al., 2012), and (ii) potentially higher $\mathrm{CO}$ emission factors during small fires that were not specifically considered in current fire emission inventories (van Leeuwen et al., 2013), we define a fire emission threshold of $1.0 \times 10^{-10} \mathrm{~kg} \mathrm{CO} \mathrm{m}^{-2} \mathrm{~s}^{-1}$. If the prior emission is less than the threshold (no fire a priori, but there could be one in reality), the SD is set as $100 \%$ of $f_{\max }$; otherwise (fire a priori, but possibly of a too small magnitude), the SD is set as the maximum value between $1.0 \times 10^{-9} \mathrm{~kg} \mathrm{CO} \mathrm{m}^{-2} \mathrm{~s}^{-1}$ and $50 \%$ of $f_{\max }$. In such a way, we allow the system to relax the constraint on the prior emission to account for undetected small emissions, but we keep the global uncertainty $\left(\sim 180 \mathrm{TgCO} \mathrm{yr}^{-1}\right)$ consistent with current bottom-up inventories (Granier et al., 2011; Van der Werf et al., 2010). For simplicity, this error setting also serves for anthropogenic fuel consumption.

The prior $\mathrm{CH}_{4}$ emission uncertainty is defined as $100 \%$ of the maximum value of the prior emissions in the grid cell and its eight neighbours in the corresponding month. The MCF prior emission uncertainty is set at $\pm 10 \%$ of the flux, as its emissions are supposed to be well known. The uncertainty of $\mathrm{CH}_{2} \mathrm{O}$ production is assumed to be $100 \%$ of its concurrent prior $\mathrm{CH}_{2} \mathrm{O}$ production. The uncertainties of initial con- centration scaling factors are set at $10 \%$ for the four species $\left(\mathrm{CO}, \mathrm{CH}_{4}, \mathrm{CH}_{2} \mathrm{O}, \mathrm{MCF}\right)$. Errors in $\mathrm{OH}$ 8-day scaling factors are set at $\pm 10 \%$.

The spatial error correlations of the a priori are assigned to all variables following Chevallier et al. (2007), defined by an e-folding length of $500 \mathrm{~km}$ over the land and $1000 \mathrm{~km}$ over the ocean. Temporal error correlations are defined by an efolding length of 8 weeks for MCF and 2 weeks for the other species including $\mathrm{OH}$. No inter-species flux error correlations are considered.

\subsection{Observations for assimilation}

\subsubsection{Data sets}

We assimilate three data streams: (i) MOPITTv6 satellite CO total column retrievals (noted as $\mathrm{X}_{\mathrm{CO}}$ hereafter) and surface in situ measurements of (ii) $\mathrm{CH}_{4}$ and (iii) MCF.

MOPITT retrievals have been available since March 2000, but the instrument experienced a cooler failure from May to August 2001, which artificially changed the retrieval mean level (Deeter et al., 2010). An instrument anomaly also led to a 2-month lack of data in 2009 from the end of July until September, without any significant change in the retrieval mean level. For the sake of consistency, given our focus on trends, we select the measurements for the decade from 2002 to 2011, during which both the MOPITT retrievals and the prior emission inventories are homogeneous (GFEDv3.1 has not been publicly updated for the years after 2011).

We use the level 2 "multispectral" near-infrared and thermal infrared (NIR/TIR) CO retrievals of MOPITTv6 that offer the best description of $\mathrm{CO}$ in the lower troposphere among the MOPITT products (Deeter et al., 2014). The MO- 
PITT vertical profiles (prior and retrieved CO profiles and associated AKs) are defined on ten vertical pressure levels. Given the limited vertical resolution of the retrievals and the focus on surface emissions, it has been common practice in previous inversion studies starting from Pétron et al. (2004) to assimilate the $700 \mathrm{hPa}$ pressure level retrievals only, as a good compromise between proximity to the surface and limited noise. However, Deeter et al. (2014) noted that the retrievals at some individual vertical levels still suffered from small bias drifts, while such drifts were not seen in the retrieved integrated columns. Furthermore, the interpretation of vertically integrated columns in the inversion is less hampered by flaws in CTM vertical mixing and vertical sink distribution than for level retrievals (Rayner and O'Brien, 2001). For these two reasons, we assimilate the column retrievals rather than level retrievals. Night-time observations, observations with a solar zenith angle larger than $70^{\circ}$, with latitudes within $25^{\circ}$ from the poles, or with surface pressures less than $900 \mathrm{hPa}$, are excluded, since they may be of lower quality or more difficult to model (Fortems-Cheiney et al., 2011). We average the $22 \times 22 \mathrm{~km}^{2}$ retrievals at the $3.75^{\circ} \times 2.5^{\circ}$ model resolution within 30 min time steps. The model $\mathrm{X}_{\mathrm{CO}}$ retrievals are calculated in a consistent way as in the MOPITT $\mathrm{X}_{\mathrm{CO}}$ retrievals with their original prior $\mathrm{CO}$ profiles and AKs averaged for each model grid.

Surface measurements of $\mathrm{CH}_{4}$ and MCF from various networks are assimilated together with MOPITT $\mathrm{X}_{\mathrm{CO}}$. The data sets are downloaded from the World Data Centre for Greenhouse Gases (WDCGG, http://ds.data.jma.go.jp/gmd/ wdcgg/). Stations that recorded more than 6 years of data without gaps larger than 1 year are included. The list of stations is given in Tables S1 and S2 in the Supplement. For the surface measurements, a data filtering process is conducted in order to remove outliers that the global model may not be able to capture. We exclude (i) observations exceeding $3 \sigma$ of the de-trended and de-seasonalized daily time series and (ii) observations whose misfit against the prior simulation exceeds $3 \sigma$ of the de-trended and de-seasonalized misfit between observations and forward modelling values.

\subsubsection{Observation error statistics}

The observation error covariance matrix $\mathbf{R}$ is diagonal in order to simplify calculations. Observation errors are combinations of measurement errors (quantified by the data providers), representativeness errors and CTM errors. For $\mathrm{X}_{\mathrm{CO}}$, as we have averaged a large number of observations in each grid box (see Sect. 2.3.1), the representativeness error is effectively much reduced and is not considered specifically. The CTM error is set at $30 \%$ (SD) of the modelled values for $\mathrm{X}_{\mathrm{CO}}$. For $\mathrm{CH}_{4}$ and $\mathrm{MCF}$, synoptic variability (estimated from the residues of de-trended and de-seasonalized data) is used as a proxy for the CTM and representativeness errors, which largely dominate the observation error. The global mean measurement error for Xco is around $6.4 \pm 2.9 \mathrm{ppb}$, which is approximately $8.2 \pm 1.9 \%$ of the corresponding $\mathrm{X}_{\mathrm{CO}}$ observations. The measurement errors are set as $3 \mathrm{ppb}$ for $\mathrm{CH}_{4}$ and $1.2 \mathrm{ppt}$ for $\mathrm{MCF}$ if not explicitly provided by the surface observation data sets.

\subsection{Observations for cross-evaluation}

We use two data sets for independent evaluation of the inversion results.

The first one is made of $\mathrm{CO}$ surface observations archived at the WDCGG. The same site selection and data filtering process as for $\mathrm{CH}_{4}$ and MCF surface measurements are applied (see the list of stations in Table S3).

The second evaluation data set gathers $\mathrm{CH}_{2} \mathrm{O}$ total columns retrieved from OMI by the Smithsonian Astrophysical Observatory (SAO). We use version 3, release 2, of this product (González Abad et al., 2015). Since these data are not available before mid-2004, they do not cover our study period completely: for the sake of consistency, we do not assimilate them (in contrast to Fortems-Cheiney et al., 2012) and we keep them for evaluation. We select observations that are tagged as "good" by the provider's quality flag, which have a solar zenith angle less than $70^{\circ}$ and a cloud cover below $20 \%$, and are not affected by the "row anomaly".

\subsection{Trend analysis}

The long-term trend in this study is estimated by least-square curve fitting of the following function, which includes a constant, a linear component, and seasonal variations represented by four harmonics:

$f(t)=a_{0}+a_{1} t+\sum_{n=1}^{4} c_{n}\left[\sin \left(2 n \pi t+\varphi_{n}\right)\right]$.

If not particularly specified, all the trends mentioned in this paper refer to $a_{1}$.

\section{CO concentrations and associated trends}

\subsection{Evaluation of the inversion framework's ability to fit the data}

Figure 4a shows the time series of the global mean mole fraction of the MOPITT $\mathrm{X}_{\mathrm{CO}}$ retrievals (black), and the prior (blue) and the posterior (red) $\mathrm{X}_{\mathrm{CO}}$ retrievals (calculated from model simulations with the MOPITT prior profiles and averaging kernels). Compared to the MOPITT $\mathrm{X}_{\mathrm{CO}}$, the prior $\mathrm{X}_{\mathrm{CO}}$ simulation is on average $15 \%$ lower when modelled with TransCom-OH and $17 \%$ lower when modelled with INCA-OH. The global mean posterior $\mathrm{X}_{\mathrm{CO}}$ fits the observation irrespective of the $\mathrm{OH}$ field used.

The spatial distribution of the multiyear mean $\mathrm{X}_{\mathrm{CO}}$ observed by MOPITT (2002-2011) shows a latitudinal gradient from north to south, with some high values over East Asia, 
Table 2. Summary of CO model-data comparison and trend analysis for MOPITT satellite retrievals, surface station observations and corresponding prior/posterior modelling. Trends for each region (in the unit of $\mathrm{ppb} \mathrm{yr}^{-1}$ ) are the mean values for all the grids whose trends are significant at the $95 \%$ confidence level. The percentages of significant trends (shown in italic) are also given per model grid for positive $(+)$ and negative $(-)$ respectively.

\begin{tabular}{|c|c|c|c|c|c|c|c|c|c|c|c|c|c|c|c|c|c|c|c|c|c|c|c|}
\hline \multirow[t]{3}{*}{ Regions } & \multicolumn{2}{|c|}{ MOPITT } & \multicolumn{2}{|c|}{ Surface } & \multicolumn{9}{|c|}{ MOPITT column trends } & \multicolumn{10}{|c|}{ Surface station trends } \\
\hline & \multirow{2}{*}{$\begin{array}{r}\text { Prior } \\
\text { bias }\end{array}$} & \multirow{2}{*}{$\begin{array}{l}\text { Post } \\
\text { bias } \\
\qquad(\mathrm{ppb})\end{array}$} & \multirow{2}{*}{$\begin{array}{r}\text { Prior } \\
\text { bias }\end{array}$} & \multirow{2}{*}{$\begin{array}{l}\text { Post } \\
\text { bias }\end{array}$} & \multirow[t]{2}{*}{$N$} & \multicolumn{3}{|c|}{ Observation } & \multicolumn{3}{|c|}{ Prior mod } & \multicolumn{2}{|c|}{ Posterior mod } & \multirow[t]{2}{*}{$N$} & \multicolumn{3}{|c|}{ Observation } & \multicolumn{3}{|c|}{ Prior mod } & \multicolumn{3}{|c|}{ Posterior mod } \\
\hline & & & & & & Trend & $\begin{array}{l}+ \\
\%\end{array}$ & \% & Trend & + & $\overline{\%}$ & Trend & $\begin{array}{ll}+ & - \\
\% & \%\end{array}$ & & Trend & $\begin{array}{l}+ \\
\%\end{array}$ & $\overline{\%}$ & Trend & $\begin{array}{l}+ \\
\%\end{array}$ & $\overline{\%}$ & Trend & $\begin{array}{l}+ \\
\%\end{array}$ & $\overline{\%}$ \\
\hline BONA & -14.1 & 0.7 & -20.8 & 20.5 & 210 & -0.84 & & 99 & -0.46 & & 95 & -0.88 & 99 & 2 & -2.51 & & 100 & -1.46 & & 100 & -2.96 & & 100 \\
\hline USA & -16.7 & -3.1 & -20.4 & 20.1 & 108 & -0.82 & & 97 & -0.41 & & 96 & -1.08 & 100 & 3 & -1.67 & & 67 & -1.13 & & 100 & -3.30 & & 100 \\
\hline NHSA & -10.0 & -3.0 & & & 74 & -0.61 & & 84 & -0.19 & 8 & 53 & -0.68 & 100 & 0 & & & & & & & & & \\
\hline SHSA & -14.2 & 0.2 & & & 160 & -0.59 & & 58 & 0.38 & 41 & & -0.56 & 67 & 0 & & & & & & & & & \\
\hline NHAF & -15.0 & -2.0 & -20.0 & 6.8 & 211 & -0.45 & 7 & 55 & -0.38 & & 85 & -0.73 & 95 & 1 & -0.90 & & 100 & -0.73 & & 100 & -1.04 & & 100 \\
\hline SHAF & -16.5 & 0.5 & -1.5 & 13.6 & 96 & -0.57 & & 75 & 0.07 & 27 & 11 & -0.64 & 96 & 1 & -0.78 & & 100 & 0.42 & 100 & & -0.48 & & 100 \\
\hline WSEU & -16.1 & 0.3 & -36.7 & 18.7 & 106 & -1.00 & & 100 & -0.49 & & 100 & -1.12 & 100 & 6 & -2.73 & & 100 & -2.05 & & 100 & -3.51 & & 100 \\
\hline ESEU & -16.8 & 0.4 & & & 108 & -0.77 & & 100 & -0.40 & & 100 & -0.93 & 100 & 0 & & & & & & & & & \\
\hline BOAS & -17.3 & 1.0 & & & 227 & -0.92 & & 99 & -0.51 & & 92 & -1.02 & 99 & 0 & & & & & & & & & \\
\hline MIDE & -16.5 & -2.9 & & & 64 & -0.57 & & 100 & -0.30 & & 100 & -0.88 & 100 & 0 & & & & & & & & & \\
\hline SCAS & -12.0 & -0.3 & & & 80 & -0.65 & & 63 & -0.30 & 4 & 38 & -0.92 & 100 & 0 & & & & & & & & & \\
\hline SEAS & -20.1 & -3.6 & -30.6 & 22.6 & 129 & -1.23 & & 97 & 0.13 & 19 & 24 & -1.35 & 99 & 3 & -1.76 & & 100 & -1.83 & & 100 & -3.78 & & 100 \\
\hline AUST & -15.5 & -1.7 & -6.4 & 15.4 & 105 & -0.62 & & 100 & 0.17 & 28 & & -0.78 & 100 & 3 & -0.34 & & 67 & - & & & -1.18 & & 67 \\
\hline INDO & -3.8 & 0.2 & & & 64 & -1.20 & & 98 & -0.84 & & 28 & -1.03 & 98 & 0 & & & & & & & & & \\
\hline OCEAN & -11.9 & -0.2 & -15.1 & 9.6 & 3092 & -0.72 & & 96 & -0.07 & 22 & 25 & -0.67 & 97 & 27 & -1.23 & 4 & 89 & -1.00 & 7 & 59 & -1.46 & & 89 \\
\hline
\end{tabular}

(a)
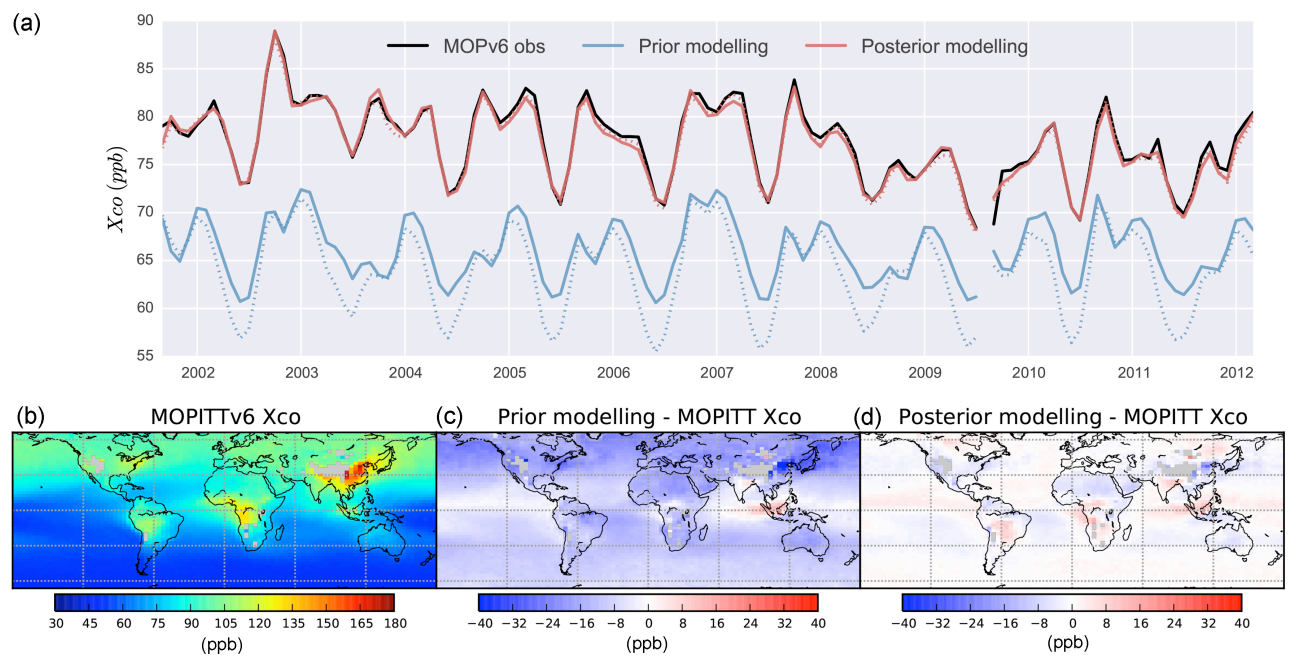

Figure 4. Time series and spatial distributions of the $\mathrm{CO}$ total column $\left(\mathrm{X}_{\mathrm{CO}}\right)$. (a) Time series of the global monthly mean mole fraction in the $\mathrm{CO}$ column. The black line represents satellite observation of MOPITTv6 $\mathrm{X}_{\mathrm{CO}}$; the blue (red) lines represent the prior (posterior) simulations. Solid lines represent the control version with TransCom-OH, and dotted lines represent the test with INCA-OH. (b) Distribution of multiyear mean annual $\mathrm{X}_{\mathrm{CO}}$ of MOPITTv6 retrieval. (c) Mean annual difference between the prior simulation and MOPITT. (d) Mean annual difference between the posterior simulation and MOPITT. Simulations shown in (c) and (d) used TransCom-OH. The results with INCA-OH show similar spatial distributions and are not shown here.

Africa and central South America (Fig. 4b). The regional mean bias of $\mathrm{X}_{\mathrm{CO}}$ in the prior and the posterior modelling compared to the MOPITT data is summarized in Table 2. The prior simulation is generally lower than the observations except in parts of Indonesia and India (Fig. 4c). This negative bias agrees with previous studies (Arellano et al., 2004; Fortems-Cheiney et al., 2011; Hooghiemstra et al., 2012; Naik et al., 2013; Shindell et al., 2006), and thus calls attention to understanding and correcting it appropriately (Stein et al., 2014). The optimized CO concentrations fit the measurements quite well (Fig. 4d), illustrating the inversion's ability to fit the data.
Similarly for $\mathrm{CH}_{4}$ and MCF, Table 3 summarizes the mean biases and residual root mean squares (rms) of the prior and posterior modelling values compared to the station observations that are assimilated in the system over four latitudinal bands. The inversion fits the assimilated data fairly well, with a considerable decrease in both the mean biases and the rms (Table 3).

The mean biases of the prior and posterior simulations compared to independent surface in situ $\mathrm{CO}$ measurements are also summarized for each region in Table 2. For the oceanic background stations (over 27 model grid cells), the magnitude of the model-data misfits decreased considerably 


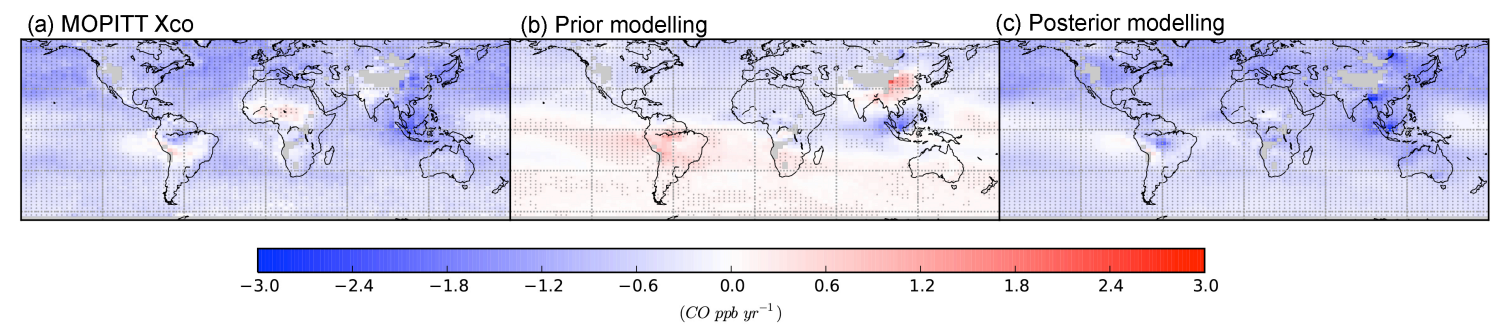

Figure 5. Distribution of CO column mixing ratio trends from 2002 to 2011 in (a) MOPITTv6 retrievals, (b) the prior simulation and (c) the posterior simulation. Black crosses indicate significance at the $95 \%$ confidence level.

after inversion. Over land, the changes in model-data misfit after inversion are more heterogeneous. The prior bias is in general negative, whereas the sign changed from negative to positive for the posterior. The magnitude of the posterior bias (also the rms, not shown in the table) decreased significantly in western Europe (WSEU), South-east Asia (SEAS) and Northern Hemisphere Africa (NHAF), and they are of similar magnitudes in boreal North America (BONA) and the USA. However, the mean bias and rms increased in Southern Hemisphere Africa (SHAF) and Australia (AUST).

This seeming deterioration of the modelled surface concentrations could be explained by several reasons: first, surface station measurements and model grids $\left(2.5 \times 3.75^{\circ}\right)$ have different spatial representativeness. In fact, at most background oceanic stations, the model-data misfit suggests an overall improvement after inversion. Second, the vertical sensitivities are different between satellite column retrievals and surface observations (Hooghiemstra et al., 2012). Over regions where fire emission injection heights are sometimes above the boundary layer (Cammas et al., 2009) or where chemical CO sources in the mid-troposphere contributes significantly to the CO column (Fisher et al., 2015), the surface CO concentrations are less influenced by these sources, but the model may not capture this vertical distribution of sources. Third, there might be a model bias in modelling the vertical $\mathrm{CO}$ profiles in the CTM (Jiang et al., 2013); for instance, when the vertical mixing in the model is too conservative, it could lead to a positive bias at the surface, because the sources are adjusted to fit the satellite data. Nevertheless, such discrepancies between $\mathrm{X}_{\mathrm{CO}}$ column and surface concentration do not seem to bear a significant trend. For instance, significant trends in the prior misfits were found in the $\mathrm{NH}$ $\left(0.67 \pm 0.24 \mathrm{ppb} \mathrm{yr}^{-1}\right)$, NH tropics $\left(0.77 \pm 0.16 \mathrm{ppb} \mathrm{yr}^{-1}\right)$ and SH tropics $\left(-0.42 \pm 0.14 \mathrm{ppbyr}^{-1}\right)$, and they are corrected in the posterior misfits to non-significant after assimilation.

\subsection{Distribution of trends in $\mathrm{CO}$ concentrations}

The spatial distributions of trends in the MOPITT $\mathrm{X}_{\mathrm{CO}}$ and in the prior and the posterior $\mathrm{X}_{\mathrm{CO}}$ over the period from 2002 to 2011 are shown successively in Fig. 5. Regional mean trends in both the $\mathrm{X}_{\mathrm{CO}}$ and surface $\mathrm{CO}$ concentrations are summarized in Table 2.

MOPITT $\mathrm{X}_{\mathrm{CO}}$ retrievals show negative trends in most regions of the world except for the Sahel region in Africa and some areas of central South America and India (Fig. 5a). In the MOPITT retrievals, the negative trends are particularly large over Indonesia $\left(-1.20 \mathrm{ppb} \mathrm{yr}^{-1}\right)$, South-east Asia $\left(-1.23 \mathrm{ppb} \mathrm{yr}^{-1}\right)$ and the North Pacific and Atlantic oceans $\left(-1.15 \mathrm{ppb} \mathrm{yr}^{-1}\right)$. The global average trend in the MOPITT $\mathrm{X}_{\mathrm{CO}}$ is $-0.67 \mathrm{ppb} \mathrm{yr}^{-1}$, accounting for a decrease of around $0.91 \% \mathrm{yr}^{-1}$ over the globe, and the trends in the prior and posterior $\mathrm{X}_{\mathrm{CO}}$ retrievals are $-0.12 \mathrm{ppb} \mathrm{yr}^{-1}\left(-0.28 \% \mathrm{yr}^{-1}\right)$ and $-0.70 \mathrm{ppb} \mathrm{yr}^{-1}\left(-0.93 \% \mathrm{yr}^{-1}\right)$ respectively. The spatial correlations between the trends of the MOPITT $\mathrm{X}_{\mathrm{CO}}$ and the prior/posterior $\mathrm{X}_{\mathrm{CO}}$ are 0.55 and 0.81 respectively, showing considerable improvements after inversion.

In general, negative trends in the prior $\mathrm{X}_{\mathrm{CO}}$ are underestimated (Fig. $5 \mathrm{~b}$ and Table 2), and positive trends are simulated over South-east Asia (19\%), Southern Hemisphere South America (41\%), South Africa (27\%), Australia (28\%), with percentages of model grid cells that have significant positive trends noted in the brackets. In addition, $22 \%$ of the oceanic grid cells are modelled with positive trends in the prior simulation, but none is noticed in the MOPITT column retrievals (Deeter et al., 2014). Trends in the posterior $\mathrm{X}_{\mathrm{CO}}$ generally agree with the MOPITT $\mathrm{X}_{\mathrm{CO}}$, and the positive trends in the prior $\mathrm{X}_{\mathrm{CO}}$ are corrected (Fig. $5 \mathrm{c}$ and Table 2).

Surface in situ measurements also show a general negative trend in $\mathrm{CO}$ concentration (Table 2). The negative trends from in situ CO stations have the largest magnitude in the $\mathrm{NH}$ mid-latitudes over western Europe $\left(-2.7 \pm 1.7 \mathrm{ppbyr}^{-1}\right)$ and the USA $\left(-1.6 \pm 0.9 \mathrm{ppbyr}^{-1}\right)$. Smaller trends are found in the SH in situ sites $\left(-0.32 \pm 0.14 \mathrm{ppbyr}^{-1}\right)$. The trends over Asia indicate large spatial heterogeneity $\left(-1.6 \pm 1.3 \mathrm{ppb} \mathrm{yr}^{-1}\right)$ and the trends over the tropics show a small but insignificant increase $\left(0.3 \pm 1.6 \mathrm{ppb} \mathrm{yr}^{-1}\right)$, but these regions are represented by a limited number of stations.

Compared to these surface in situ measurements, the prior simulation generally tends to underestimate the magnitude of the negative ones, and the posterior slightly overestimate them. The global mean trends are $-1.3 \mathrm{ppbyr}^{-1}\left(-1.1 \% \mathrm{yr}^{-1}\right)$ in the observation, 
Table 3. Fitness of $\mathrm{CH}_{4}$ and MCF observations assimilated in the inversion.

\begin{tabular}{|c|c|c|c|c|c|c|c|c|c|}
\hline \multirow[t]{3}{*}{ Region } & \multirow[t]{3}{*}{ OH type } & \multicolumn{4}{|c|}{$\mathrm{CH}_{4}(\mathrm{ppb})$} & \multicolumn{4}{|c|}{ MCF (ppt) } \\
\hline & & \multicolumn{2}{|c|}{ Mean bias } & \multicolumn{2}{|c|}{ Residual square } & \multicolumn{2}{|c|}{ Mean bias } & \multicolumn{2}{|c|}{ Residual square } \\
\hline & & Prior & Posterior & Prior & Posterior & Prior & Posterior & Prior & Posterior \\
\hline \multirow[t]{2}{*}{$\mathrm{NH}(30-90)$} & TransCom & 20.6 & 2.4 & 749.6 & 22.2 & 1.02 & -0.02 & 1.14 & 0.05 \\
\hline & INCA & -21.0 & 2.5 & 658.1 & 20.1 & 0.44 & -0.09 & 0.28 & 0.07 \\
\hline \multirow[t]{2}{*}{$\mathrm{NH}(0-30)$} & TransCom & 15.8 & 1.5 & 452.6 & 19.1 & 0.90 & -0.20 & 0.91 & 0.16 \\
\hline & INCA & -21.1 & -0.1 & 564.9 & 13.9 & 0.40 & -0.20 & 0.21 & 0.11 \\
\hline \multirow[t]{2}{*}{$\mathrm{SH}(0-30)$} & TransCom & 10.9 & -2.4 & 222.1 & 20.1 & 1.19 & 0.09 & 1.61 & 0.13 \\
\hline & INCA & -14.3 & -4.0 & 264.9 & 29.5 & 0.88 & 0.23 & 0.94 & 0.15 \\
\hline \multirow[t]{2}{*}{ SH(30-90) } & TransCom & 14.4 & 0.2 & 308.3 & 4.7 & 0.88 & -0.24 & 0.90 & 0.17 \\
\hline & INCA & -7.9 & -0.4 & 96.6 & 5.7 & 0.60 & -0.06 & 0.46 & 0.07 \\
\hline
\end{tabular}

$-0.87 \mathrm{ppb} \mathrm{yr}^{-1}\left(-0.75 \% \mathrm{yr}^{-1}\right)$ in the prior simulations, and $-1.9 \mathrm{ppb} \mathrm{yr}^{-1}\left(-1.2 \% \mathrm{yr}^{-1}\right)$ in the posterior simulations. However, it is noted that the global mean trends are only represented by 72 stations that are not evenly distributed over the globe. Positive trends in the prior simulated surface $\mathrm{CO}$ are less visible compared to the total column as shown in Fig. $5 \mathrm{~b}$ and Table 2 . It could be explained by the respective vertical weighting of these two observation types, but the difference may also be enhanced by changes in the MOPITT AKs if the retrieval prior is biased (Yoon et al., 2013). However, this comparison is limited by the representativeness of a few sites.

\section{Concentrations of $\mathrm{CH}_{2} \mathrm{O}$ and $\mathrm{OH}$}

\section{1 $\mathrm{CH}_{2} \mathrm{O}$ columns}

The mean time series of $\mathrm{CH}_{2} \mathrm{O}$ total columns for four latitudinal zones are shown in Fig. 6. $\mathrm{X}_{\mathrm{CH}_{2} \mathrm{O}}$ retrievals were not assimilated (contrary to the $\mathrm{CH}_{4}$ and MCF surface measurements that affect the sources and sinks of $\mathrm{CH}_{2} \mathrm{O}$ in the inversion), and the inversion actually does not change $\mathrm{X}_{\mathrm{CH}_{2} \mathrm{O}}$ much. This suggests that the differences between simulated and satellite-retrieved $\mathrm{X}_{\mathrm{CH}_{2} \mathrm{O}}$ are mainly caused by the prior NMVOC emissions used in the full chemistry run of LMDzINCA. The latitudinal mean values of prior/posterior modelled $\mathrm{X}_{\mathrm{CH}_{2} \mathrm{O}}$ agree fairly well with the OMI retrievals without any obvious bias, but the seasonal cycle is different, especially in the northern mid-high latitudes both in phase

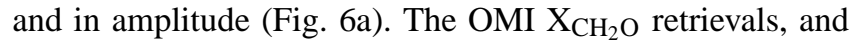
the prior and the posterior simulations, all agree about the absence of a significant trend in the latitudinal average of $\mathrm{X}_{\mathrm{CH}_{2} \mathrm{O}}$ for the period from 2005 to 2011, which is consistent with the hypothesis that the equilibrium between the oxidation of hydrocarbons into $\mathrm{CH}_{2} \mathrm{O}$ and the sink of $\mathrm{CH}_{2} \mathrm{O}$ into $\mathrm{CO}$ has not significantly changed, at least at continental scales. We note that the $\mathrm{OMI} \mathrm{X}_{\mathrm{CH}_{2} \mathrm{O}}$ retrievals describe some trends at smaller scales, like positive trends of $3 \pm 0.8 \% \mathrm{yr}^{-1}$ over East Asia (De Smedt et al., 2010) and negative trends of $-1.9 \pm 0.6 \% \mathrm{yr}^{-1}$ over the Amazon, but they are not significant for the mean values of large latitudinal bands and are thus considered large enough to influence the global $\mathrm{CO}$ budget.

\subsection{OH concentrations}

Figure 7 shows the latitudinal average of the prior (blue) and posterior (red) $\mathrm{OH}$ concentrations for the six big regions over which $\mathrm{OH}$ is optimized (see Sect. 2.1). This figure reports the two inversions that use either TransCom-OH (solid lines) or INCA-OH (dashed lines; see Sect. 2.2.1). INCA has higher $\mathrm{OH}$ concentrations than TransCom in the $\mathrm{NH}$, in particular during summer, but lower $\mathrm{OH}$ concentrations in the $\mathrm{SH}$ tropics all year long and slightly lower concentrations in the $\mathrm{SH}$ mid-high latitudes (south of $30^{\circ} \mathrm{S}$ ) during summer peaks.

In general, larger corrections are applied by the inversion to INCA-OH than to TransCom-OH. The inversion system adjusts the INCA-OH concentrations towards TransCom-OH by downscaling the $\mathrm{OH}$ concentrations in the $\mathrm{NH}$ during summers, especially over Asia, where INCA-OH is considerably higher than the TransCom-OH (Fig. 3). A small reduction of the TransCom-OH concentrations is also seen in the $\mathrm{SH}$.

The two inversions do not produce significant trends in $\mathrm{OH}$ during the study period for most regions, except for a very small positive trend in the $\mathrm{SH}$ tropics $\left(+0.2 \% \mathrm{yr}^{-1}\right.$ with TransCom-OH and $+0.7 \% \mathrm{yr}^{-1}$ with INCA-OH) and a small negative trend in the $\mathrm{SH}$ mid-high latitudes $\left(-0.4 \% \mathrm{yr}^{-1}\right.$ in TransCom-OH and $-0.3 \% \mathrm{yr}^{-1}$ in INCA-OH). Such small and insignificant trends are considered to be of minor importance for the $\mathrm{CO}$ trends. The $\mathrm{OH}$ scaling is addressed in more detail in Sect. 5.1 when discussing CO sinks. 

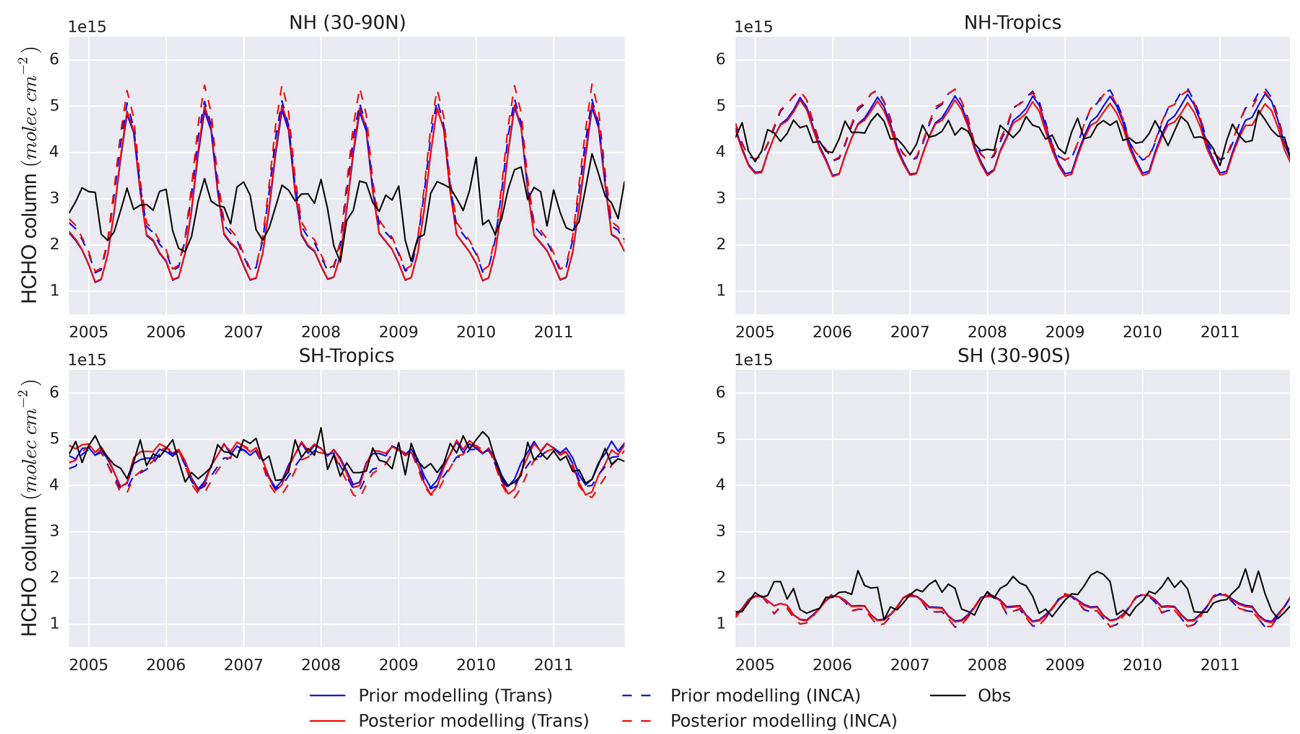

Figure 6. Time series of the $\mathrm{CH}_{2} \mathrm{O}$ total column averaged by latitudinal bands. The black lines indicate the $\mathrm{CH}_{2} \mathrm{O}$ total column from $\mathrm{SAO}$ OMI retrievals, green lines indicate prior simulations, and red lines indicate posterior simulations. Shading areas show the standard deviation within a latitudinal band. The forward and posterior simulations nearly overlay each other.

\section{Optimized sources and sinks of $\mathrm{CO}$}

After having documented the prior and posterior misfits with MOPITTv6 and with cross-validation data for the latitudinal mean values and for the trends, which lends support to the consistency of the inversion results with these data streams, we now turn to the implications for CO sources and sinks.

\subsection{Inverted CO budget}

The global annual CO atmospheric burden, surface emissions, chemical production, and chemical loss of the prior and the posteriors with the two $\mathrm{OH}$ experiments from 2002 to 2011 are shown in Fig. 8. Averaging over the 10 years, a considerable increase in the mean $\mathrm{CO}$ atmospheric burden $(+23 \%$, in dark green $)$ is seen in the posterior compared to the prior simulation. Accordingly, increases in $\mathrm{CO}$ emissions $(+50 \%$, in red) and chemical sinks with $\mathrm{OH}(+23 \%$, in purple) are produced in the posterior, whereas only a very small change is noticed for the $\mathrm{CO}$ chemical sources $(+1 \%$, in blue). The magnitude of the increment in the global $\mathrm{CO}$ emissions is larger compared to previous studies that assimilate the $700 \mathrm{hPa}$ retrieval levels of MOPITT using a similar inversion set-up (Fortems-Cheiney et al., 2011, 2012). The cross-evaluation against surface station measurements also shows a considerable positive bias in the posterior $\mathrm{CO}$ concentration (Sect. 3.1), which implies a potential bias in the modelling of vertical CO profiles. Nevertheless, for our study here focusing on trends, such systematic model error does not seem to harm the robustness of the trends as shown in Sects. 3 and 4. The chemical sink of $\mathrm{CO}$ is a function of both $\mathrm{CO}$ and $\mathrm{OH}$. Given the results for $\mathrm{OH}$ adjustments shown in
Sect. 4.2 (generally a small reduction from the prior $\mathrm{OH}$ ), the increase in the $\mathrm{CO}$ sink in the posterior is thus mainly due to the increase in $\mathrm{CO}$ concentrations after assimilation.

The inversion produces a negative trend of around $10 \%$ per decade in the global atmospheric burden of $\mathrm{CO}\left(-5.1 \pm 0.9 \mathrm{TgCO} \mathrm{yr}^{-1}\right.$ with TransCom-OH and $-4.6 \pm 0.8 \mathrm{TgCO} \mathrm{yr}^{-1}$ with INCA-OH), which is twice the negative trend of the $\mathrm{CO}$ atmospheric burden produced by

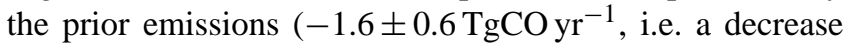
of $5 \%$ per decade in the simulated $\mathrm{CO}$ burden).

For $\mathrm{CO}$ sources, the trend of prior $\mathrm{CO}$ emissions is of $-11.1 \pm 4.4 \mathrm{TgCO} \mathrm{yr}^{-1}$ (equivalent to a decrease of $10 \%$ per decade). This is mostly contributed by the negative trend in biomass burning emissions in GFEDv3.1 $\left(-10.6 \pm 3.7 \mathrm{TgCO} \mathrm{yr}^{-1}\right)$ and by a very small decrease in anthropogenic emissions in MACCity $\left(-0.68 \pm 0.4 \mathrm{TgCO} \mathrm{yr}^{-1}\right)$ from 2002 to 2011 . Compared to the prior emissions, a 2 -fold steeper negative trend in terms of percentages is found in the posterior CO emissions, $24 \%$ per decade with TransCom-OH $\left(-40 \pm 7.2 \mathrm{TgCO} \mathrm{yr}^{-1}\right)$ and $22 \%$ per decade with INCA-OH $\left(-37 \pm 7.1 \mathrm{TgCO} \mathrm{yr}^{-1}\right)$. A small positive trend $\left(2.8 \pm 7.1 \mathrm{TgCO} \mathrm{yr}^{-1}\right.$, equivalent to an increase of $2 \%$ per decade) is produced in the prior $\mathrm{CO}$ chemical production, mostly contributed by the increase in methane oxidation. The posterior $\mathrm{CO}$ chemical production shows a small negative trend. Yet, as $\mathrm{CH}_{2} \mathrm{O}$ concentrations are not constrained by observations, this small trend may result from the system's inability to differentiate the two $\mathrm{CO}$ sources between surface emissions and chemical oxidations.

For the $\mathrm{CO}$ sink, a larger trend in the posterior $\left(-46.3 \pm 8.3 \mathrm{TgCO} \mathrm{yr}^{-1}, 16 \%\right.$ per decade $)$ with TransCom- 

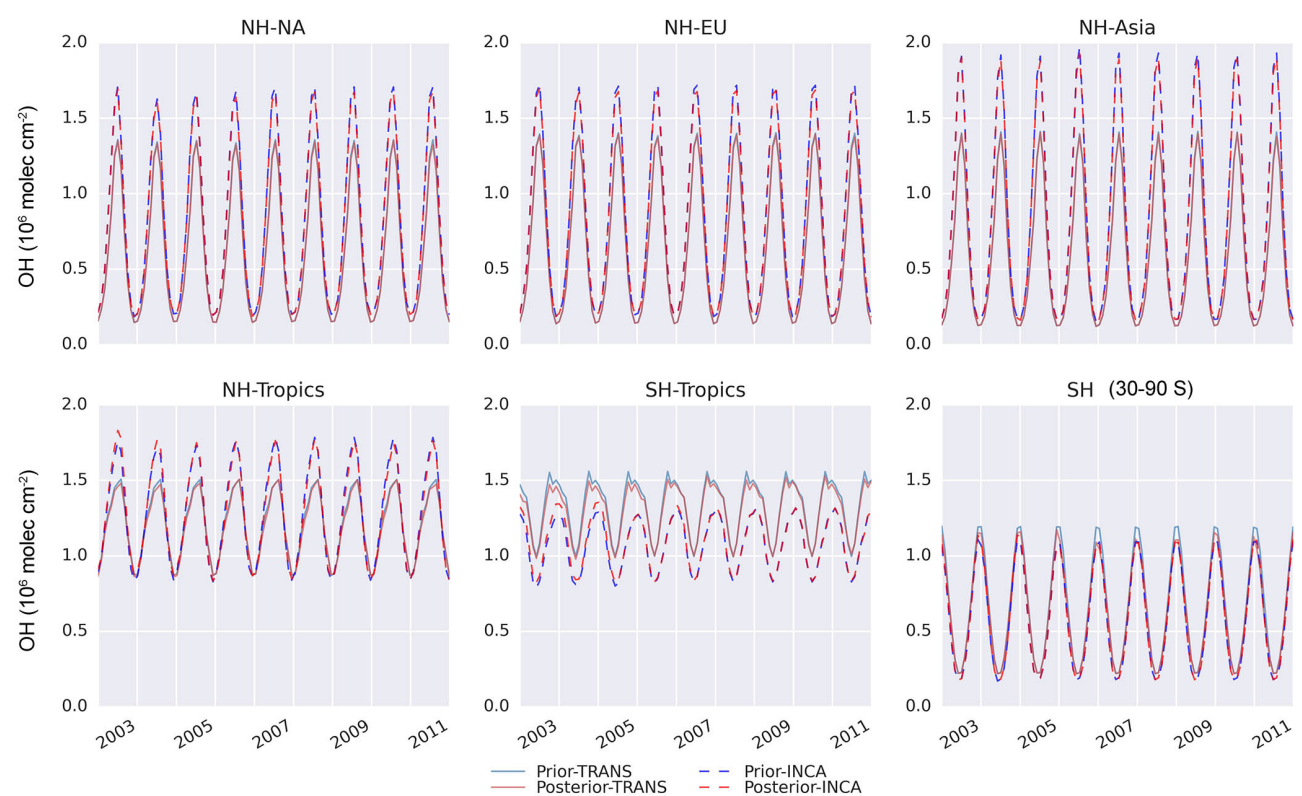

Figure 7. Regional volume-weighted monthly mean $\mathrm{OH}$ concentrations in the prior and posterior. The results are shown for the six big regions in which $\mathrm{OH}$ is optimized.

$\mathrm{OH}$ and $-39.3 \pm 8.0 \mathrm{TgCO} \mathrm{yr}^{-1}, 13 \%$ per decade with INCA-OH is found, while there is no significant trend in the prior chemical sink. This negative trend in the posterior is mostly due to the decrease in $\mathrm{CO}$ concentrations in the atmosphere that change the amount of $\mathrm{CO}$ oxidized by $\mathrm{OH}$, and only very small trends in the $\mathrm{OH}$ concentrations are found by the inversion. Such small trends are considered to have a very small effect on the $\mathrm{CO}$ trends. The $\mathrm{OH}$ concentrations are optimized for six big regions over the globe and the MCF concentrations are monitored at background sites only, which allows a coarse zonal estimate of $\mathrm{OH}$ but leaves spatially heterogeneous land areas unconstrained, e.g. polluted areas near cities (Hofzumahaus et al., 2009), forests with high NMVOC emissions (Lelieveld et al., 2008) or biomass burning plumes (Folkins et al., 1997; Rohrer et al., 2014). Therefore, subregional trends in $\mathrm{OH}$, if they exist, are not necessarily captured in this study. In addition, with the exponential decrease of MCF concentrations in recent years (only a few parts per trillion, ppt, at the current level), the constraining strength of MCF on $\mathrm{OH}$ in the inversion system may not be even from 2002 to 2011, even though the same sites and a similar number of observations were assimilated. Nevertheless, the zonal trend of $\mathrm{OH}$ should still be constrained throughout most of the period and previous studies suggest that the inter-annual change of global $\mathrm{OH}$ concentration is within $5 \%$ (Montzka et al., 2011).

\subsection{Regional distribution of trends in $\mathrm{CO}$ emissions}

The distributions of trends in $\mathrm{CO}$ emissions after optimization are very consistent using either TransCom-OH or INCA-
OH (Fig. 9); therefore, only trends of TransCom-OH experiments are discussed here. The relative contribution of biomass burning to the total land surface emissions estimated in the prior emission is shown in Fig. 2b. The time series of the prior and the two posterior annual $\mathrm{CO}$ emissions using two different $\mathrm{OH}$ fields are shown for each sub-region in Fig. 10. The division in sub-regions is illustrated in Fig. A1 in the Appendix. As shown in Fig. 10, the choice of prior $\mathrm{OH}$ concentrations could potentially have a large impact on the regional $\mathrm{CO}$ emission estimates; nevertheless, the inverted emission trends are quite robust and we do not discuss further in this paper the regional emission increments and the sensitivities of inverted fluxes to prior $\mathrm{OH}$ or chemical $\mathrm{CO}$ productions.

For the boreal regions where $\mathrm{CO}$ emissions are mainly due to biomass burning (boreal Asia - BOAS - and boreal North America - BONA), the same sign of the trends in CO emissions is mostly kept between the prior and the posterior, but the amplitudes of the trends are updated into larger values, as are the emission amounts. It should be noted that MOPITT $\mathrm{CO}$ retrievals over high latitudes beyond $65^{\circ}$ are not included in the assimilation.

For the $\mathrm{NH}$ mid-latitudes where $\mathrm{CO}$ emissions are mainly due to fossil fuel and biofuel burning emissions (USA; western Europe - WSEU; eastern Europe - ESEU; Middle East - MIDE; South-Central Asia - SCAS; South-east Asia SEAS), consistencies between the trends in the prior and posterior $\mathrm{CO}$ emissions are found in the developed countries (Fig. 9). For example, in the USA and WSEU regions, decreasing trends produced by the emission inventories generally agree with the atmospheric signals (Lamarque et al., 


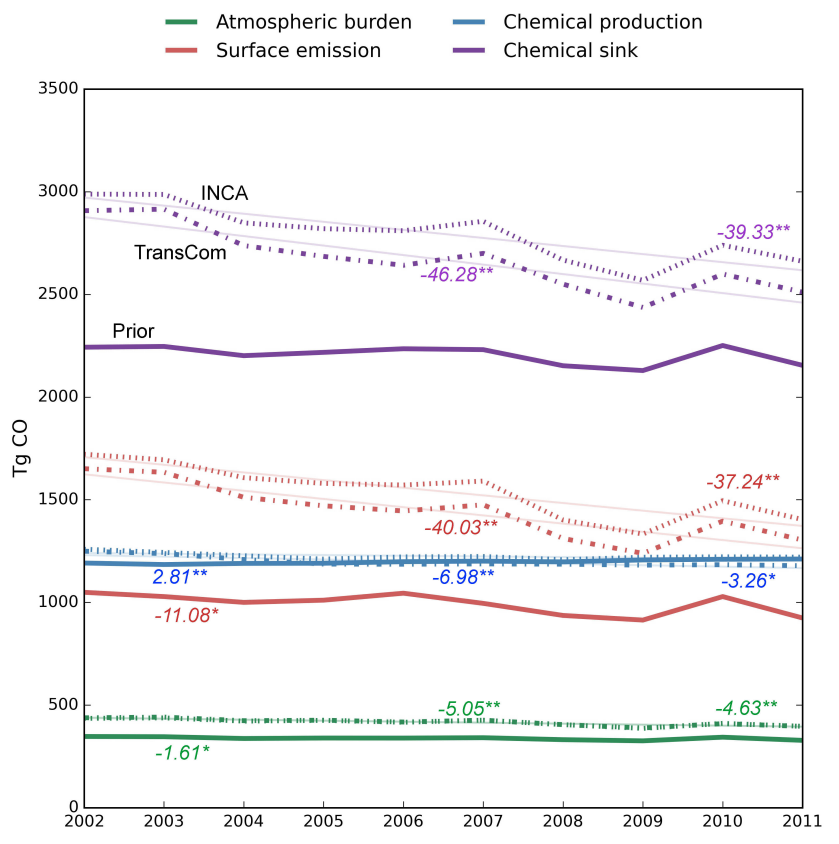

Figure 8. Time series of global mean annual $\mathrm{CO}$ budget changes from 2002 to 2011. Solid lines indicate the prior values (mean values of the two $\mathrm{OH}$ fields are shown for the prior chemical $\mathrm{CO}$ production and sink). Dash-dot lines indicate posterior with TransCom $\mathrm{OH}$ and dotted lines represent posterior with INCA-OH. Beside each line, the linear slopes are denoted if the trend is statistically significant, ${ }^{*}$ denotes the $95 \%$ confidence level and ${ }^{* *}$ denotes the $99 \%$ confidence level.

2010). On the contrary, the inversion changes the sign of the CO trend over SEAS (including China) and SCAS (including India), where the prior emissions suggested a significant increase. Consistent with our posterior emissions, a gradual decrease in $\mathrm{CO}$ emissions in China after the year 2005 was actually deduced from $\mathrm{CH}_{4} / \mathrm{CO}_{2}$ and $\mathrm{CO} / \mathrm{CO}_{2}$ correlations observed off the coast of East Asia from 1999 to 2010 (Tohjima et al., 2014). A decrease in the emission factors of other co-emitted species of $\mathrm{CO}$ during fossil fuel or biofuel combustion has also been noted: for instance, a decrease in black carbon emission factors in China and India was reported by Wang et al. (2014), and a decrease in the relative ratio of $\mathrm{NO}_{x}$ to $\mathrm{CO}_{2}$ from 2003 to 2011 was observed from satellite retrievals over East Asia (Reuter et al., 2014). These studies and our results suggest that combustion technology improvements in East Asia resulted in emission factor reduction to an extent that outweighs the impact of increasing fossil fuel burning. In this scenario, emission inventories would well report the latter but not the former, which is more difficult to quantify. In addition, trends of fossil fuel emissions are updated (Lamarque et al., 2010), but not trends of biofuel burning, especially for traditional biofuels (Yevich and Logan, 2003). A small difference in the trend of CO emissions in eastern Europe (ESEU) is also noticed (not signifi-
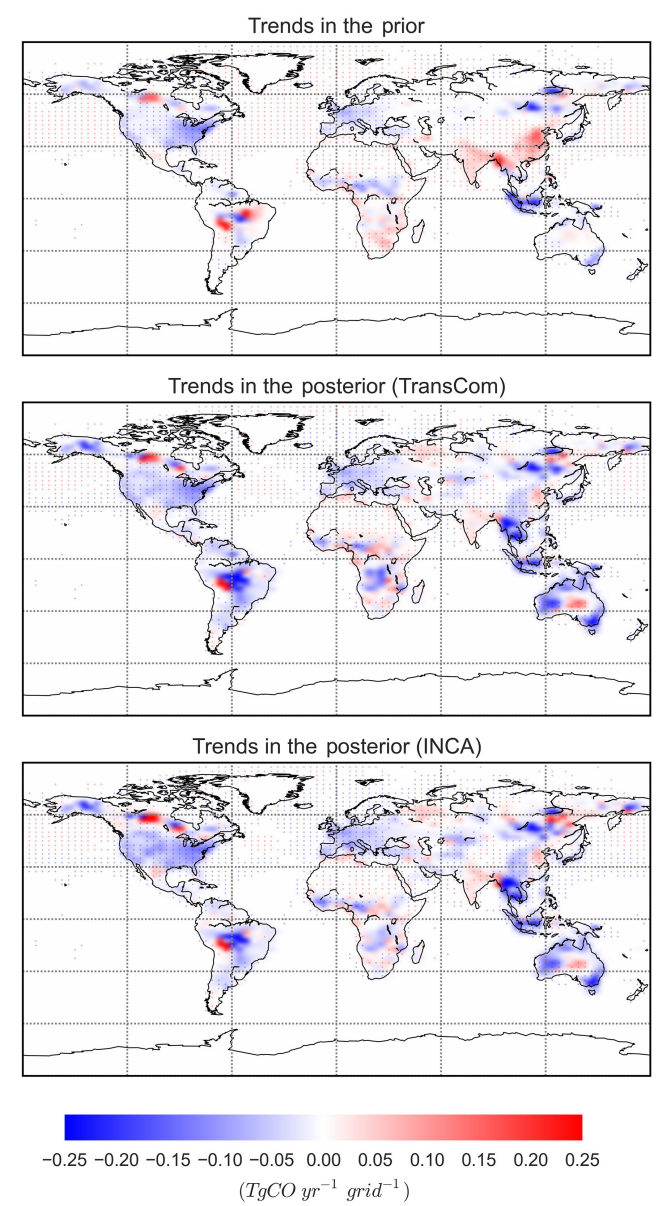

Figure 9. Trends distributions of $\mathrm{CO}$ surface emissions in the prior and in the posterior from 2002 to 2011.

cant though); an emission peak in the year 2010 is inferred from the inversion.

For the tropical and sub-tropical regions, where $\mathrm{CO}$ emissions are mainly attributed to biomass burning, the inversion does not change the sign of trends over Indonesia (INDO). The positive trends of the prior emissions over the IndoChina Peninsula $\left(2 \% \mathrm{yr}^{-1}\right)$ are updated into negative ones $\left(-5.6 \% \mathrm{yr}^{-1}\right)$ by the inversion. Negative trends over Australia except for the central area (on average $-5.3 \% \mathrm{yr}^{-1}$ ), and over SHSA $\left(-3 \% \mathrm{yr}^{-1}\right.$, but not significant for the regional mean) are largely enhanced compared to the prior trends (Fig. 9). The spatial distribution of this negative trend is consistent with the new version of GFEDv4 burned area (not used in this study) (Giglio et al., 2013), which accounts for small fires that were not explicitly included in GFEDv3.1 used here as the prior. In Australia, the decrease of $\mathrm{CO}$ emissions might be explained by decreased fire emissions (Poulter et al., 2014). The decrease in SHSA could be attributed to a decrease in deforestation fires in recent years, especially after 2005 (Meyfroidt and Lambin, 2011), although there are 

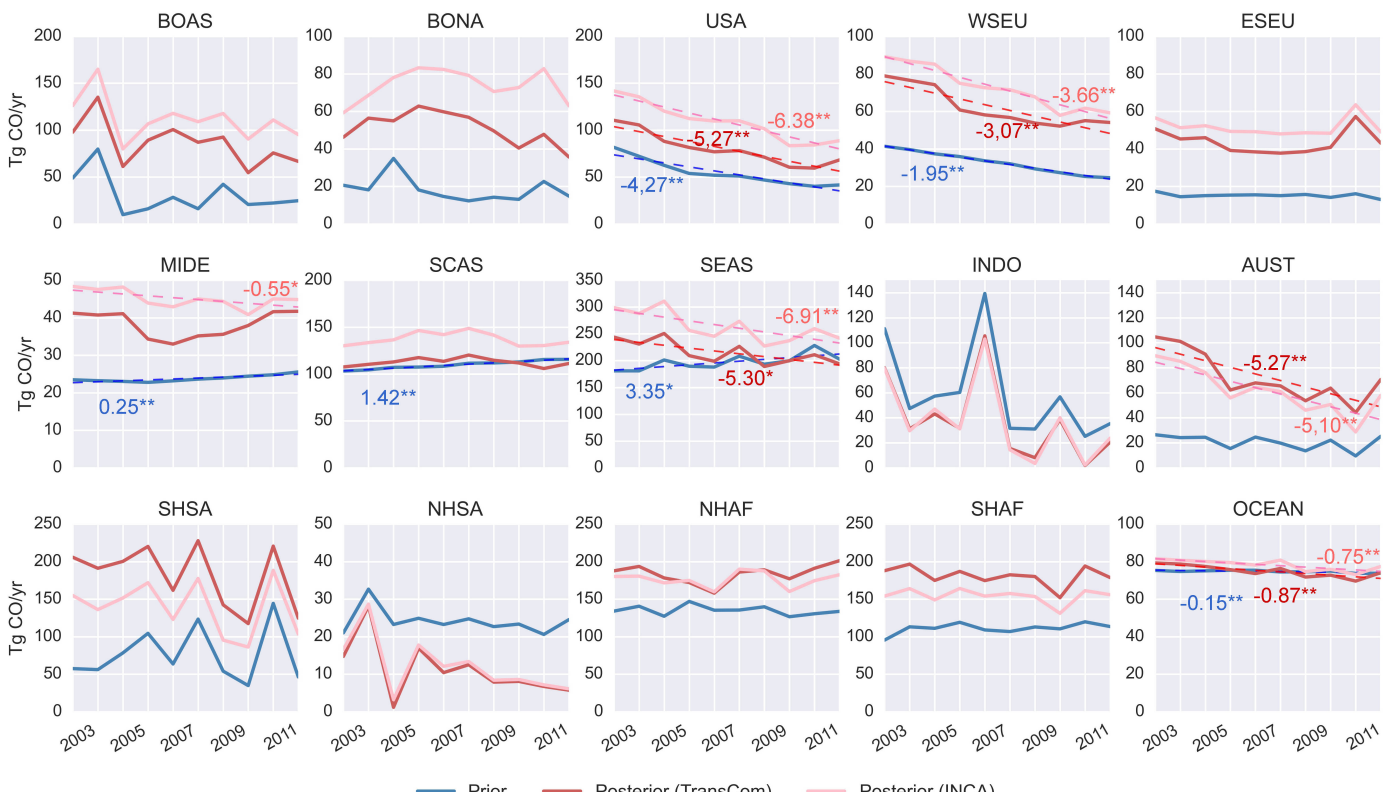

Figure 10. Annual prior (blue) and posterior (red) CO emissions in each sub-region from 2002 to 2011. The dash lines represent linear regressions if the trend is statistically significant. The slopes are denoted beside the linear trends; ${ }^{*}$ and ${ }^{* *}$ represent significance at the 95 and $99 \%$ confidence levels respectively. The notation for the sub-regions is listed as follows and the extent of each region is shown in Fig. A1. BOAS - boreal Asia; BONA - boreal North America; USA - USA; WSEU - western Europe; ESEU - eastern Europe; MIDE Middle East; SCAS - South-Central Asia; SEAS - South-east Asia; INDO - Indonesia; AUST - Australia; NHSA - Northern Hemisphere South America; SHSA - Southern Hemisphere South America; NHAF - Northern Hemisphere Africa; SHAF - Southern Hemisphere Africa; OCEAN - all ocean emissions, both biogenic and anthropogenic emissions.

uncertainties in the overall deforestation rates (Kim et al., 2015).

The change in trends between the prior and posterior $\mathrm{CO}$ emissions is more heterogeneous over Africa (Northern Hemisphere Africa - NHAF - and Southern Hemisphere Africa - SHAF). Decreases in the burned area have been observed over the NHAF Sahel region, as are decreases in the prior $\mathrm{CO}$ emissions, which are explained by changes in both precipitation and the conversion of savannah into cropland (Andela and van der Werf, 2014). But positive trends in $\mathrm{CO}$ emissions are inferred by the atmospheric inversion especially since 2006, except for some small areas. The different signs of the trend in burned areas (or the prior CO emissions) and the posterior $\mathrm{CO}$ emissions may be explained by the change in $\mathrm{CO}$ emission factors that could vary a lot with the conversion of fire type from savannah fire to agricultural burning and also with precipitation change (van Leeuwen et al., 2013). In addition, increases in anthropogenic fossil fuel and biofuel emission in the NHAF region could also contribute to some of the differences (Al-mulali and Binti Che Sab, 2012). Differences between the prior and posterior $\mathrm{CO}$ emissions are also noticed for the central part of the SHAF. The increase in the GFED4 burned area is explained by the increase in precipitation that allows more fuel accumulation, as driven by the El Niño-Southern Oscillation (ENSO) changes from El Niño to La Niña dominance over the recent decade (Andela and van der Werf, 2014). The opposite negative trend of $\mathrm{CO}$ emissions in the posterior could be explained by a decrease in $\mathrm{CO}$ emission factors when the fuel load and combustion completeness are high, so that less carbon is emitted in the form of $\mathrm{CO}$, but the dynamics of emission factors are not modelled in the bottom-up estimation (van Leeuwen et al., 2013). In addition, small fires that are not considered in our prior biomass emissions could also contribute to such differences (Randerson et al., 2012).

\section{Conclusion}

CO concentrations observed by both MOPITTv6 satellite $\mathrm{X}_{\mathrm{CO}}$ retrievals and surface in situ measurements show significant negative trends over most of the world from 2002 to 2011. The CO concentration trends in the forward CTM simulations prescribed with $\mathrm{CO}$ emission inventories show considerable inconsistency with the observed MOPITT $\mathrm{X}_{\mathrm{CO}}$ from 2002 to 2011. By assimilating MOPITTv6 $X_{\mathrm{CO}}$ and surface measurements of $\mathrm{CH}_{4}$ and MCF, the inversion system suggests that the decrease in the atmospheric $\mathrm{CO}$ concentrations is mainly attributable to a decrease of $23 \%$ in surface emissions during the study period at the global scale. The trends in the prior and posterior $\mathrm{CO}$ emissions agree well with each other over the USA and western Europe. The largest differences between the prior and the posterior $\mathrm{CO}$ 
emission trends are noticed for South-east Asia, Australia and parts of South America and Africa. Decreases in CO emissions are found in central China, while the prior emission inventories suggest increases. This emission decrease is probably caused by a large decrease in emission factors due to technology improvements that outweigh the increase in emission activities. $\mathrm{CO}$ emissions from biomass burning decreased considerably in Indonesia and Australia. For Africa, the contrasts of trends between the prior and the posterior likely reflect different trends between satellite-detected burned area and $\mathrm{CO}$ emissions due to changes in combustion completeness, $\mathrm{CO}$ emission factors, and the relative contribution of small fires. The amplitude of the trends also differs in many other regions, illustrating the original information brought by atmospheric inversions about $\mathrm{CO}$ emissions.

No significant trend is found in the latitudinal-mean $\mathrm{OH}$ concentrations, and a sensitivity test made with two different $\mathrm{OH}$ fields suggests consistent results in the $\mathrm{OH}$ trend. It is however noted that we optimized $\mathrm{OH}$ over six big regions globally, and sub-regional trends in the $\mathrm{OH}$ concentrations, if they exist, are not accounted for in this study. We also acknowledge the limited information content of MCF to constrain $\mathrm{OH}$ in recent years over the study period. For chemical $\mathrm{CH}_{2} \mathrm{O}$ production from NMVOC oxidation, the system has the potential to generate regional increments, but $\mathrm{CH}_{2} \mathrm{O}$ is not assimilated here due to limited temporal coverage of the OMI data from 2005 to 2011. Assimilating observations of $\mathrm{CH}_{2} \mathrm{O}$ and other chemically connected species could inform more about regional $\mathrm{CO}$ budgets, in particular the chemical sources and sinks, and therefore could further improve the top-down estimation of $\mathrm{CO}$ budgets for each region in future studies. 
Appendix A

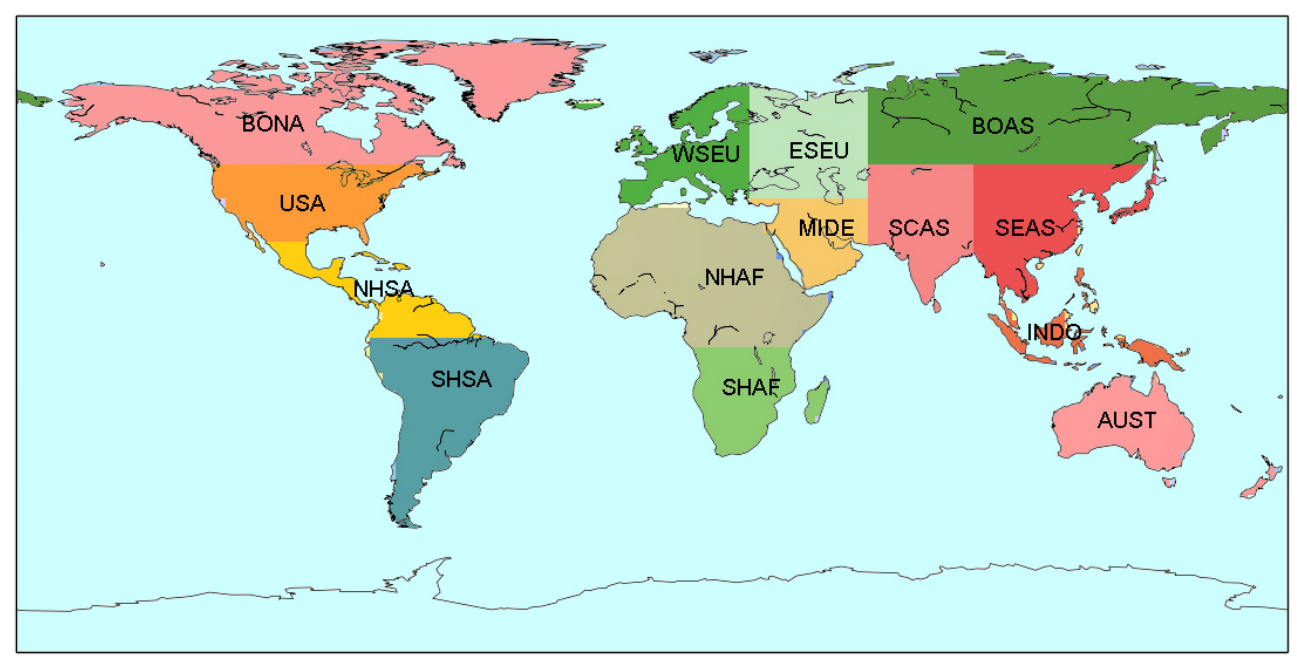

Figure A1. Sub-region extent. 


\section{The Supplement related to this article is available online at doi:10.5194/acp-15-13433-2015-supplement.}

Acknowledgements. The authors acknowledge the support of the French Agence Nationale de la Recherche (ANR) under grant ANR-10-BLAN-0611 (project TropFire). F. Chevallier is funded by the European Commission under the EU H2020 Programme (grant agreement no. 630080, MACC III). The NCAR MOPITT and the SAO OMI retrievals are available from https://www2.acd.ucar.edu/mopitt and http://disc.sci.gsfc.nasa. gov/Aura/data-holdings/OMI/omhcho_v003.shtml, respectively. We thank both institutes for having brought these data into open access and thank G. González Abad for helpful information about the OMI product. Similarly, we also acknowledge the WDCGG for providing the archives of surface station observations for $\mathrm{MCF}, \mathrm{CH}_{4}$ and $\mathrm{CO}$. We thank the following persons who have participated in the surface in situ measurements through various networks: NOAA (E. Dlugokencky, G. S. Dutton, J. W. Elkins, S. A. Montzka, P. C. Novelli), CSIRO (P. B. Krummel, R. L. Langenfelds, L. P. Steele), EC (D. Worthy), Empa (B. Buchmann, M. Steinbacher, L. Emmenegger), JMA (Y. Fukuyama), LSCE (M. Ramonet), NIWA (G. Brailsford, S. Nichol, R. Spoor), UBA (K. Uhse), UNIURB (J. Arduini), and AGAGE (P. J. Fraser, C. M. Harth, P. B. Krummel, S. O'Doherty, R. Prinn, S. Reimann, L. P. Steele, M. Vollmer, R. Wang, R. Weiss, D. Young). Finally, we wish to thank F. Marabelle and his team for computer support at LSCE.

Edited by: A. Pozzer

\section{References}

Al-mulali, U. and Binti Che Sab, C. N.: The impact of energy consumption and $\mathrm{CO}_{2}$ emission on the economic growth and financial development in the Sub Saharan African countries, Energy, 39, 180-186, doi:10.1016/j.energy.2012.01.032, 2012.

Andela, N. and van der Werf, G. R.: Recent trends in African fires driven by cropland expansion and El Niño to La Niña transition, Nature Climate Change, 4, 791-795, doi:10.1038/nclimate2313, 2014.

Angelbratt, J., Mellqvist, J., Simpson, D., Jonson, J. E., Blumenstock, T., Borsdorff, T., Duchatelet, P., Forster, F., Hase, F., Mahieu, E., De Mazière, M., Notholt, J., Petersen, A. K., Raffalski, U., Servais, C., Sussmann, R., Warneke, T., and Vigouroux, C.: Carbon monoxide $(\mathrm{CO})$ and ethane $\left(\mathrm{C}_{2} \mathrm{H}_{6}\right)$ trends from ground-based solar FTIR measurements at six European stations, comparison and sensitivity analysis with the EMEP model, Atmos. Chem. Phys., 11, 9253-9269, doi:10.5194/acp-11-92532011, 2011.

Arellano, A. F., Kasibhatla, P. S., Giglio, L., van der Werf, G. R., and Randerson, J. T.: Top-down estimates of global CO sources using MOPITT measurements, Geophys. Res. Lett., 31, L01104, doi:10.1029/2003GL018609, 2004.

Aumont, O. and Bopp, L.: Globalizing results from ocean in situ iron fertilization studies, Global Biogeochem. Cy., 20, GB2017, doi:10.1029/2005GB002591, 2006.
Bergamaschi, P., Hein, R., Heimann, M., and Crutzen, P. J.: Inverse modeling of the global CO cycle: 1 . Inversion of CO mixing ratios, J. Geophys. Res., 105, 1909, doi:10.1029/1999JD900818, 2000.

Butler, T. M., Rayner, P. J., Simmonds, I., and Lawrence, M. G.: Simultaneous mass balance inverse modeling of methane and carbon monoxide, J. Geophys. Res., 110, D21310, doi:10.1029/2005JD006071, 2005.

Cammas, J.-P., Brioude, J., Chaboureau, J.-P., Duron, J., Mari, C., Mascart, P., Nédélec, P., Smit, H., Pätz, H.-W., Volz-Thomas, A., Stohl, A., and Fromm, M.: Injection in the lower stratosphere of biomass fire emissions followed by long-range transport: a MOZAIC case study, Atmos. Chem. Phys., 9, 5829-5846, doi:10.5194/acp-9-5829-2009, 2009.

Chevallier, F., Fisher, M., Peylin, P., Serrar, S., Bousquet, P., Bréon, F. M., Chédin, A., and Ciais, P.: Inferring $\mathrm{CO}_{2}$ sources and sinks from satellite observations: Method and application to TOVS data, J. Geophys. Res., 110, D24309, doi:10.1029/2005JD006390, 2005.

Chevallier, F., Bréon, F.-M., and Rayner, P. J.: Contribution of the Orbiting Carbon Observatory to the estimation of $\mathrm{CO}_{2}$ sources and sinks: Theoretical study in a variational data assimilation framework, J. Geophys. Res., 112, D09307, doi:10.1029/2006JD007375, 2007.

Chevallier, F., Fortems, A., Bousquet, P., Pison, I., Szopa, S., Devaux, M., and Hauglustaine, D. A.: African CO emissions between years 2000 and 2006 as estimated from MOPITT observations, Biogeosciences, 6, 103-111, doi:10.5194/bg-6-103-2009, 2009.

Cressot, C., Chevallier, F., Bousquet, P., Crevoisier, C., Dlugokencky, E. J., Fortems-Cheiney, A., Frankenberg, C., Parker, R., Pison, I., Scheepmaker, R. A., Montzka, S. A., Krummel, P. B., Steele, L. P., and Langenfelds, R. L.: On the consistency between global and regional methane emissions inferred from SCIAMACHY, TANSO-FTS, IASI and surface measurements, Atmos. Chem. Phys., 14, 577-592, doi:10.5194/acp-14-577-2014, 2014.

Deeter, M. N.: Operational carbon monoxide retrieval algorithm and selected results for the MOPITT instrument, J. Geophys. Res., 108, 4399, doi:10.1029/2002JD003186, 2003.

Deeter, M. N., Edwards, D. P., Gille, J. C., Emmons, L. K., Francis, G., Ho, S. P., Mao, D., Masters, D., Worden, H., Drummond, J. R., and Novelli, P. C.: The MOPITT version 4 CO product: Algorithm enhancements, validation, and long-term stability, J. Geophys. Res., 115, doi:10.1029/2009JD013005, 2010.

Deeter, M. N., Martínez-Alonso, S., Edwards, D. P., Emmons, L. K., Gille, J. C., Worden, H. M., Pittman, J. V., Daube, B. C., and Wofsy, S. C.: Validation of MOPITT Version 5 thermalinfrared, near-infrared, and multispectral carbon monoxide profile retrievals for 2000-2011, J. Geophys. Res.-Atmos., 118, 6710-6725, 2013.

Deeter, M. N., Martínez-Alonso, S., Edwards, D. P., Emmons, L. K., Gille, J. C., Worden, H. M., Sweeney, C., Pittman, J. V., Daube, B. C., and Wofsy, S. C.: The MOPITT Version 6 product: algorithm enhancements and validation, Atmos. Meas. Tech., 7, 3623-3632, doi:10.5194/amt-7-3623-2014, 2014.

De Smedt, I., Stavrakou, T., Müller, J.-F., van der A, R. J., and Van Roozendael, M.: Trend detection in satellite observations of formaldehyde tropospheric columns, Geophys. Res. Lett., 37, L18808, doi:10.1029/2010GL044245, 2010. 
Duncan, B. N. and Logan, J. A.: Model analysis of the factors regulating the trends and variability of carbon monoxide between 1988 and 1997, Atmos. Chem. Phys., 8, 7389-7403, doi:10.5194/acp-8-7389-2008, 2008.

Duncan, B. N., Logan, J. A., Bey, I., Megretskaia, I. A., Yantosca, R. M., Novelli, P. C., Jones, N. B., and Rinsland, C. P.: Global budget of CO, 1988-1997: Source estimates and validation with a global model, J. Geophys. Res., 112, D22301, doi:10.1029/2007JD008459, 2007.

EPA: National Trends in CO Levels, available at: http://www.epa. gov/airtrends/carbon.html, last access: 12 February 2015.

Fisher, J. A., Wilson, S. R., Zeng, G., Williams, J. E., Emmons, L. K., Langenfelds, R. L., Krummel, P. B., and Steele, L. P.: Seasonal changes in the tropospheric carbon monoxide profile over the remote Southern Hemisphere evaluated using multi-model simulations and aircraft observations, Atmos. Chem. Phys., 15, 3217-3239, doi:10.5194/acp-15-3217-2015, 2015.

Folberth, G. A., Hauglustaine, D. A., Lathière, J., and Brocheton, F.: Interactive chemistry in the Laboratoire de Météorologie Dynamique general circulation model: model description and impact analysis of biogenic hydrocarbons on tropospheric chemistry, Atmos. Chem. Phys., 6, 2273-2319, doi:10.5194/acp-62273-2006, 2006.

Folkins, I., Wennberg, P. O., Hanisco, T. F., Anderson, J. G., and Salawitch, R. J.: $\mathrm{OH}, \mathrm{HO}_{2}$, and $\mathrm{NO}$ in two biomass burning plumes: Sources of $\mathrm{HO}_{x}$ and implications for ozone production, Geophys. Res. Lett., 24, 3185-3188, doi:10.1029/97GL03047, 1997.

Fortems-Cheiney, A., Chevallier, F., Pison, I., Bousquet, P., Carouge, C., Clerbaux, C., Coheur, P.-F., George, M., Hurtmans, D., and Szopa, S.: On the capability of IASI measurements to inform about $\mathrm{CO}$ surface emissions, Atmos. Chem. Phys., 9, 87358743, doi:10.5194/acp-9-8735-2009, 2009.

Fortems-Cheiney, A., Chevallier, F., Pison, I., Bousquet, P., Szopa, S., Deeter, M. N., and Clerbaux, C.: Ten years of $\mathrm{CO}$ emissions as seen from Measurements of Pollution in the Troposphere (MOPITT), J. Geophys. Res., 116, D05304, doi:10.1029/2010JD014416, 2011.

Fortems-Cheiney, A., Chevallier, F., Pison, I., Bousquet, P., Saunois, M., Szopa, S., Cressot, C., Kurosu, T. P., Chance, K., and Fried, A.: The formaldehyde budget as seen by a global-scale multiconstraint and multi-species inversion system, Atmos. Chem. Phys., 12, 6699-6721, doi:10.5194/acp-12-6699-2012, 2012.

Giglio, L., Randerson, J. T., and van der Werf, G. R.: Analysis of daily, monthly, and annual burned area using the fourthgeneration global fire emissions database (GFED4), J. Geophys. Res.-Biogeo., 118, 317-328, doi:10.1002/jgrg.20042, 2013.

González Abad, G., Liu, X., Chance, K., Wang, H., Kurosu, T. P., and Suleiman, R.: Updated Smithsonian Astrophysical Observatory Ozone Monitoring Instrument (SAO OMI) formaldehyde retrieval, Atmos. Meas. Tech., 8, 19-32, doi:10.5194/amt-8-192015, 2015.

Granier, C., Bessagnet, B., Bond, T., D’Angiola, A., Denier van der Gon, H., Frost, G. J., Heil, A., Kaiser, J. W., Kinne, S., Klimont, Z., Kloster, S., Lamarque, J.-F., Liousse, C., Masui, T., Meleux, F., Mieville, A., Ohara, T., Raut, J.-C., Riahi, K., Schultz, M. G., Smith, S. J., Thompson, A., Aardenne, J., Werf, G. R., and Vuuren, D. P.: Evolution of anthropogenic and biomass burning emissions of air pollutants at global and regional scales during the 1980-2010 period, Climatic Change, 109, 163-190, doi:10.1007/s10584-011-0154-1, 2011.

Hauglustaine, D. A.: Interactive chemistry in the Laboratoire de Météorologie Dynamique general circulation model: Description and background tropospheric chemistry evaluation, J. Geophys. Res., 109, D04314, doi:10.1029/2003JD003957, 2004.

Hofzumahaus, A., Rohrer, F., Lu, K., Bohn, B., Brauers, T., Chang, C.-C., Fuchs, H., Holland, F., Kita, K., Kondo, Y., Li, X., Lou, S., Shao, M., Zeng, L., Wahner, A., and Zhang, Y.: Amplified trace gas removal in the troposphere, Science, 324, 1702-1704, doi:10.1126/science.1164566, 2009.

Holloway, T., Levy, H., and Kasibhatla, P.: Global distribution of carbon monoxide, J. Geophys. Res., 105, 12123, doi:10.1029/1999JD901173, 2000.

Hooghiemstra, P. B., Krol, M. C., Bergamaschi, P., de Laat, A. T. J., Van der Werf, G. R., Novelli, P. C., Deeter, M. N., Aben, I., and Röckmann, T.: Comparing optimized CO emission estimates using MOPITT or NOAA surface network observations, J. Geophys. Res., 117, D06309, doi:10.1029/2011JD017043, 2012.

Hourdin, F., Musat, I., Bony, S., Braconnot, P., Codron, F., Dufresne, J.-L., Fairhead, L., Filiberti, M.-A., Friedlingstein, P., Grandpeix, J.-Y., Krinner, G., LeVan, P., Li, Z.-X., and Lott, F.: The LMDZ4 general circulation model: climate performance and sensitivity to parametrized physics with emphasis on tropical convection, Clim. Dynam., 27, 787-813, doi:10.1007/s00382006-0158-0, 2006.

IPCC: Abstract for decision-makers, in: Climate Change 2013: The Physical Science Basis. Contribution of Working Group I to the Fifth Assessment Report of the Intergovernmental Panel on Climate Change, edited by: Stocker, T. F., Qin, D., Plattner, G.-K., Tignor, M., Allen, S. K., Boschung, J., Nauels, A., Xia, Y., Bex, V., and Midgley, P. M., Cambridge University Press, Cambridge, UK and New York, NY, USA, 2013.

Jiang, Z., Jones, D. B. A., Worden, H. M., Deeter, M. N., Henze, D. K., Worden, J., Bowman, K. W., Brenninkmeijer, C. A. M., and Schuck, T. J.: Impact of model errors in convective transport on $\mathrm{CO}$ source estimates inferred from MOPITT CO retrievals, J. Geophys. Res.-Atmos., 118, 2073-2083, doi:10.1002/jgrd.50216, 2013.

Khalil, M. A. K. and Rasmussen, R. A.: Carbon monoxide in the Earth's atmosphere: indications of a global increase, Nature, 332, 242-245, 1988.

Kim, D.-H., Sexton, J. O., and Townshend, J. R.: Accelerated Deforestation in the Humid Tropics from the 1990s to the 2000s, Geophys. Res. Lett., doi:10.1002/2014GL062777, 2015.

Kopacz, M., Jacob, D. J., Fisher, J. A., Logan, J. A., Zhang, L., Megretskaia, I. A., Yantosca, R. M., Singh, K., Henze, D. K., Burrows, J. P., Buchwitz, M., Khlystova, I., McMillan, W. W., Gille, J. C., Edwards, D. P., Eldering, A., Thouret, V., and Nedelec, P.: Global estimates of CO sources with high resolution by adjoint inversion of multiple satellite datasets (MOPITT, AIRS, SCIAMACHY, TES), Atmos. Chem. Phys., 10, 855-876, doi:10.5194/acp-10-855-2010, 2010.

Kurokawa, J., Ohara, T., Morikawa, T., Hanayama, S., JanssensMaenhout, G., Fukui, T., Kawashima, K., and Akimoto, H.: Emissions of air pollutants and greenhouse gases over Asian regions during 2000-2008: Regional Emission inventory in ASia (REAS) version 2, Atmos. Chem. Phys., 13, 11019-11058, doi:10.5194/acp-13-11019-2013, 2013. 
Lamarque, J.-F., Bond, T. C., Eyring, V., Granier, C., Heil, A., Klimont, Z., Lee, D., Liousse, C., Mieville, A., Owen, B., Schultz, M. G., Shindell, D., Smith, S. J., Stehfest, E., Van Aardenne, J., Cooper, O. R., Kainuma, M., Mahowald, N., McConnell, J. R., Naik, V., Riahi, K., and van Vuuren, D. P.: Historical (1850-2000) gridded anthropogenic and biomass burning emissions of reactive gases and aerosols: methodology and application, Atmos. Chem. Phys., 10, 7017-7039, doi:10.5194/acp10-7017-2010, 2010.

Lelieveld, J., Butler, T. M., Crowley, J. N., Dillon, T. J., Fischer, H., Ganzeveld, L., Harder, H., Lawrence, M. G., Martinez, M., Taraborrelli, D., and Williams, J.: Atmospheric oxidation capacity sustained by a tropical forest, Nature, 452, 737-740, doi:10.1038/nature06870, 2008.

Li, L. and Liu, Y.: Space-borne and ground observations of the characteristics of CO pollution in Beijing, 2000-2010, Atmos. Environ., 45, 2367-2372, doi:10.1016/j.atmosenv.2011.02.026, 2011.

Logan, J. A., Prather, M. J., Wofsy, S. C., and McElroy, M. B.: Tropospheric Chemistry: A Global Perspective, J. Geophys. Res., 86, 1-45, doi:10.1029/JC086iC08p07210, 1981.

Mao, J., Ren, X., Zhang, L., Van Duin, D. M., Cohen, R. C., Park, J.-H., Goldstein, A. H., Paulot, F., Beaver, M. R., Crounse, J. D., Wennberg, P. O., DiGangi, J. P., Henry, S. B., Keutsch, F. N., Park, C., Schade, G. W., Wolfe, G. M., Thornton, J. A., and Brune, W. H.: Insights into hydroxyl measurements and atmospheric oxidation in a California forest, Atmos. Chem. Phys., 12, 8009-8020, doi:10.5194/acp-12-8009-2012, 2012.

Meyfroidt, P. and Lambin, E. F.: Global Forest Transition: Prospects for an End to Deforestation, Annu. Rev. Env. Resour., 36, 343371, doi:10.1146/annurev-environ-090710-143732, 2011.

Montzka, S. A., Krol, M., Dlugokencky, E., Hall, B., Jockel, P., and Lelieveld, J.: Small Interannual Variability of Global Atmospheric Hydroxyl. Science, American Association for the Advancement of Science, 331, 67-69, 2011.

Mu, M., Randerson, J. T., van der Werf, G. R., Giglio, L., Kasibhatla, P., Morton, D., Collatz, G. J., DeFries, R. S., Hyer, E. J., Prins, E. M., Griffith, D. W. T., Wunch, D., Toon, G. C., Sherlock, V., and Wennberg, P. O.: Daily and 3-hourly variability in global fire emissions and consequences for atmospheric model predictions of carbon monoxide, J. Geophys. Res.-Atmos., 116, D24303, doi:10.1029/2011JD016245, 2011.

Naik, V., Voulgarakis, A., Fiore, A. M., Horowitz, L. W., Lamarque, J.-F., Lin, M., Prather, M. J., Young, P. J., Bergmann, D., Cameron-Smith, P. J., Cionni, I., Collins, W. J., Dalsøren, S. B., Doherty, R., Eyring, V., Faluvegi, G., Folberth, G. A., Josse, B., Lee, Y. H., MacKenzie, I. A., Nagashima, T., van Noije, T. P. C., Plummer, D. A., Righi, M., Rumbold, S. T., Skeie, R., Shindell, D. T., Stevenson, D. S., Strode, S., Sudo, K., Szopa, S., and Zeng, G.: Preindustrial to present-day changes in tropospheric hydroxyl radical and methane lifetime from the Atmospheric Chemistry and Climate Model Intercomparison Project (ACCMIP), Atmos. Chem. Phys., 13, 5277-5298, doi:10.5194/acp-13-5277-2013, 2013.

Novelli, P. C., Masarie, K. A., Lang, P. M., Hall, B. D., Myers, R. C., and Elkins, J. W.: Reanalysis of tropospheric CO trends: Effects of the 1997-1998 wildfires, J. Geophys. Res.-Atmos., 108, 4464, doi:10.1029/2002JD003031, 2003.

Patra, P. K., Houweling, S., Krol, M., Bousquet, P., Belikov, D., Bergmann, D., Bian, H., Cameron-Smith, P., Chipperfield, M. P.,
Corbin, K., Fortems-Cheiney, A., Fraser, A., Gloor, E., Hess, P., Ito, A., Kawa, S. R., Law, R. M., Loh, Z., Maksyutov, S., Meng, L., Palmer, P. I., Prinn, R. G., Rigby, M., Saito, R., and Wilson, C.: TransCom model simulations of $\mathrm{CH}_{4}$ and related species: linking transport, surface flux and chemical loss with $\mathrm{CH}_{4}$ variability in the troposphere and lower stratosphere, Atmos. Chem. Phys., 11, 12813-12837, doi:10.5194/acp-11-12813-2011, 2011.

Pétron, G.: Inverse modeling of carbon monoxide surface emissions using Climate Monitoring and Diagnostics Laboratory network observations, J. Geophys. Res., 107, 4761, doi:10.1029/2001JD001305, 2002.

Pétron, G., Granier, C., Khattatov, B., Yudin, V., Lamarque, J.-F., Emmons, L., Gille, J., and Edwards, D. P.: Monthly CO surface sources inventory based on the 2000-2001 MOPITT satellite data, Geophys. Res. Lett., 31, L21107, doi:10.1029/2004GL020560, 2004.

Pison, I., Bousquet, P., Chevallier, F., Szopa, S., and Hauglustaine, D.: Multi-species inversion of $\mathrm{CH}_{4}, \mathrm{CO}$ and $\mathrm{H}_{2}$ emissions from surface measurements, Atmos. Chem. Phys., 9, 5281-5297, doi:10.5194/acp-9-5281-2009, 2009.

Poulter, B., Frank, D., Ciais, P., Myneni, R. B., Andela, N., Bi, J., Broquet, G., Canadell, J. G., Chevallier, F., Liu, Y. Y., Running, S. W., Sitch, S., and van der Werf, G. R.: Contribution of semiarid ecosystems to interannual variability of the global carbon cycle, Nature, 509, 600-603, doi:10.1038/nature13376, 2014.

Randerson, J. T., Chen, Y., van der Werf, G. R., Rogers, B. M., and Morton, D. C.: Global burned area and biomass burning emissions from small fires, J. Geophys. Res., 117, G04012, doi:10.1029/2012JG002128, 2012.

Rayner, P. J. and O'Brien, D. M.: The utility of remotely sensed CO 2 concentration data in surface source inversions, Geophys. Res. Lett., 28, 175-178, doi:10.1029/2000GL011912, 2001.

Reuter, M., Buchwitz, M., Hilboll, A., Richter, A., Schneising, O., Hilker, M., Heymann, J., Bovensmann, H., and Burrows, J. P.: Decreasing emissions of $\mathrm{NO}_{x}$ relative to $\mathrm{CO}_{2}$ in East Asia inferred from satellite observations, Nat. Geosci., 7, 792-795, doi:10.1038/ngeo2257, 2014.

Rohrer, F., Lu, K., Hofzumahaus, A., Bohn, B., Brauers, T., Chang, C.-C., Fuchs, H., Häseler, R., Holland, F., Hu, M., Kita, K., Kondo, Y., Li, X., Lou, S., Oebel, A., Shao, M., Zeng, L., Zhu, T., Zhang, Y., and Wahner, A.: Maximum efficiency in the hydroxylradical-based self-cleansing of the troposphere, Nat. Geosci., 7, 559-563, doi:10.1038/ngeo2199, 2014.

Shindell, D. T., Faluvegi, G., Stevenson, D. S., Krol, M. C., Emmons, L. K., Lamarque, J.-F., Pétron, G., Dentener, F. J., Ellingsen, K., Schultz, M. G., Wild, O., Amann, M., Atherton, C. S., Bergmann, D. J., Bey, I., Butler, T., Cofala, J., Collins, W. J., Derwent, R. G., Doherty, R. M., Drevet, J., Eskes, H. J., Fiore, A. M., Gauss, M., Hauglustaine, D. A., Horowitz, L. W., Isaksen, I. S. A., Lawrence, M. G., Montanaro, V., Müller, J.-F., Pitari, G., Prather, M. J., Pyle, J. A., Rast, S., Rodriguez, J. M., Sanderson, M. G., Savage, N. H., Strahan, S. E., Sudo, K., Szopa, S., Unger, N., van Noije, T. P. C., Zeng, G.: Multimodel simulations of carbon monoxide: Comparison with observations and projected near-future changes, J. Geophys. Res., 111, D19306, doi:10.1029/2006JD007100, 2006.

Stavrakou, T. and Müller, J.-F.: Grid-based versus big region approach for inverting CO emissions using Measurement of Pollu- 
tion in the Troposphere (MOPITT) data, J. Geophys. Res., 111, D15304, doi:10.1029/2005JD006896, 2006.

Stein, O., Schultz, M. G., Bouarar, I., Clark, H., Huijnen, V., Gaudel, A., George, M., and Clerbaux, C.: On the wintertime low bias of Northern Hemisphere carbon monoxide found in global model simulations, Atmos. Chem. Phys., 14, 9295-9316, doi:10.5194/acp-14-9295-2014, 2014.

Tohjima, Y., Kubo, M., Minejima, C., Mukai, H., Tanimoto, H., Ganshin, A., Maksyutov, S., Katsumata, K., Machida, T., and Kita, K.: Temporal changes in the emissions of $\mathrm{CH}_{4}$ and $\mathrm{CO}$ from China estimated from $\mathrm{CH}_{4} / \mathrm{CO}_{2}$ and $\mathrm{CO} / \mathrm{CO}_{2}$ correlations observed at Hateruma Island, Atmos. Chem. Phys., 14, 1663-1677, doi:10.5194/acp-14-1663-2014, 2014.

van der Werf, G. R., Randerson, J. T., Giglio, L., Collatz, G. J., Kasibhatla, P. S., and Arellano Jr., A. F.: Interannual variability in global biomass burning emissions from 1997 to 2004, Atmos. Chem. Phys., 6, 3423-3441, doi:10.5194/acp-6-3423-2006, 2006.

van der Werf, G. R., Randerson, J. T., Giglio, L., Collatz, G. J., Mu, M., Kasibhatla, P. S., Morton, D. C., DeFries, R. S., Jin, Y., and van Leeuwen, T. T.: Global fire emissions and the contribution of deforestation, savanna, forest, agricultural, and peat fires (19972009), Atmos. Chem. Phys., 10, 11707-11735, doi:10.5194/acp10-11707-2010, 2010.

van Leeuwen, T. T., Peters, W., Krol, M. C., and van der Werf, G. R.: Dynamic biomass burning emission factors and their impact on atmospheric CO mixing ratios, J. Geophys. Res.-Atmos., 118, 6797-6815, doi:10.1002/jgrd.50478, 2013.
Wang, R., Tao, S., Shen, H., Huang, Y., Chen, H., Balkanski, Y., Boucher, O., Ciais, P., Shen, G., Li, W., Zhang, Y., Chen, Y., Lin, N., Su, S., Li, B., Liu, J., and Liu, W.: Trend in global black carbon emissions from 1960 to 2007, Environ. Sci. Technol., 48, 6780-6787, doi:10.1021/es5021422, 2014.

Warner, J., Carminati, F., Wei, Z., Lahoz, W., and Attié, J.-L.: Tropospheric carbon monoxide variability from AIRS under clear and cloudy conditions, Atmos. Chem. Phys., 13, 12469-12479, doi:10.5194/acp-13-12469-2013, 2013.

Worden, H. M., Deeter, M. N., Frankenberg, C., George, M., Nichitiu, F., Worden, J., Aben, I., Bowman, K. W., Clerbaux, C., Coheur, P. F., de Laat, A. T. J., Detweiler, R., Drummond, J. R. Edwards, D. P., Gille, J. C., Hurtmans, D., Luo, M., MartínezAlonso, S., Massie, S., Pfister, G., and Warner, J. X.: Decadal record of satellite carbon monoxide observations, Atmos. Chem. Phys., 13, 837-850, doi:10.5194/acp-13-837-2013, 2013.

Yevich, R. and Logan, J. A.: An assessment of biofuel use and burning of agricultural waste in the developing world, Global Biogeochem. Cy., 17, 1095, doi:10.1029/2002GB001952, 2003.

Yoon, J. and Pozzer, A.: Model-simulated trend of surface carbon monoxide for the 2001-2010 decade, Atmos. Chem. Phys., 14, 10465-10482, doi:10.5194/acp-14-10465-2014, 2014.

Zellweger, C., Hüglin, C., Klausen, J., Steinbacher, M., Vollmer, M., and Buchmann, B.: Inter-comparison of four different carbon monoxide measurement techniques and evaluation of the long-term carbon monoxide time series of Jungfraujoch, Atmos. Chem. Phys., 9, 3491-3503, doi:10.5194/acp-9-3491-2009, 2009 . 